\title{
Review
}

\section{Cortical Hyperexcitability in the Driver's Seat in ALS}

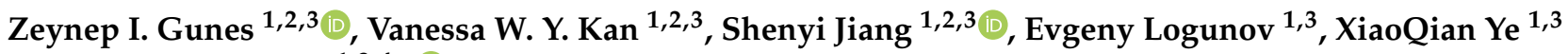 \\ and Sabine Liebscher $1,3,4, *$ (D)
}

1 Institute of Clinical Neuroimmunology, Klinikum der Universität München, Ludwig Maximilians University Munich, 82152 Munich, Germany; zeynep.guenes@med.uni-muenchen.de (Z.I.G.); wing.kan@med.uni-muenchen.de (V.W.Y.K.); shenyi.jiang@med.uni-muenchen.de (S.J.); evgeny.logunov@campus.lmu.de (E.L.); xiao.ye@med.uni-muenchen.de (X.Y.)

2 Graduate School of Systemic Neurosciences, Ludwig Maximilians University Munich, 82152 Munich, Germany

3 Biomedical Center, Ludwig Maximilians University Munich, 82152 Munich, Germany

4 Munich Cluster for Systems Neurology (SyNergy), 81377 Munich, Germany

* Correspondence: sabine.liebscher@med.uni-muenchen.de

Citation: Gunes, Z.I.; Kan, V.W.Y.; Jiang, S.; Logunov, E.; Ye, X.;

Liebscher, S. Cortical

Hyperexcitability in the Driver's Seat in ALS. Clin. Transl. Neurosci. 2022, 6, 5. https://doi.org/10.3390/ ctn6010005

Academic Editor:

Dominik Straumann

Received: 25 November 2021

Accepted: 2 February 2022

Published: 10 February 2022

Publisher's Note: MDPI stays neutral with regard to jurisdictional claims in published maps and institutional affiliations.

Copyright: () 2022 by the authors Licensee MDPI, Basel, Switzerland. This article is an open access article distributed under the terms and conditions of the Creative Commons Attribution (CC BY) license (https:// creativecommons.org/licenses/by/ $4.0 /)$.

\begin{abstract}
Amyotrophic lateral sclerosis (ALS) is a fatal disease characterized by the degeneration of cortical and spinal motor neurons. With no effective treatment available to date, patients face progressive paralysis and eventually succumb to the disease due to respiratory failure within only a few years. Recent research has revealed the multifaceted nature of the mechanisms and cell types involved in motor neuron degeneration, thereby opening up new therapeutic avenues. Intriguingly, two key features present in both ALS patients and rodent models of the disease are cortical hyperexcitability and hyperconnectivity, the mechanisms of which are still not fully understood. We here recapitulate current findings arguing for cell autonomous and non-cell autonomous mechanisms causing cortical excitation and inhibition imbalance, which is involved in the degeneration of motor neurons in ALS. Moreover, we will highlight recent evidence that strongly indicates a cardinal role for the motor cortex as a main driver and source of the disease, thus arguing for a corticofugal trajectory of the pathology.
\end{abstract}

Keywords: amyotrophic lateral sclerosis; excitability; upper motor neurons; neurodegeneration; motor cortex; microcircuit; interneurons; astrocytes

\section{Introduction}

Amyotrophic lateral sclerosis (ALS) is a lethal disease that is primarily characterized by the loss of upper motor neurons (UMN) in the cortex and lower motor neurons (LMN) in the spinal cord $[1,2]$. Being one of the most common forms of adult motor neuron diseases, ALS occurs at an incidence of $\sim 2 / 100,000$ person per year and a prevalence of $\sim 6 / 100,000$ people [3]. An ever-growing list of genes and gene variants is linked to the development of ALS [4], but only a mere $5-10 \%$ of all cases are familial (fALS) due to inherited genetic mutations, while the large majority of cases (90-95\%) are sporadic (sALS) [5-7]. Both forms of the disease progress rapidly. The initial muscle weakness, spasticity, and fasciculations soon worsen to cause severe paralysis and eventual fatal respiratory failure, typically within 3-5 years [8]. The mean age of onset of ALS is $\sim 60$ years, while in fALS the disease onset already occurs about 5 years earlier [9]. To date, only $40-60 \%$ of the familial cases could be linked to known mutations, such as the hexanucleotide repeat expansion in the Chromosome 9 open reading frame 72 (C9orf72, 40\% of fALS cases) or mutations in the Superoxide dismutase 1 (SOD1, 20\%), the TAR DNA-binding protein (TARDBP, $4 \%$ ), or in the Fused in sarcoma (FUS, 3\%) gene [7,10].

A common pathophysiological feature of ALS is the intracellular aggregation of proteinaceous deposits. The most frequently found (97\% of all ALS cases) cytoplasmic aggre- 
gates in fALS and sALS consist of the TAR DNA-binding protein of $43 \mathrm{kDa}$ (TDP-43) [11,12]. C9orf72 mutation carriers also display dipeptide repeat proteins [13]. Less frequent are aggregates of FUS, although the actual occurrence rate is a matter of debate [14,15], or SOD1 [16,17]. Genetic insight derived from fALS cases has enabled researchers to study the molecular mechanisms of the disease using animal and in vitro cell culture models. Although the complex molecular changes accompanying motor neuron loss remain to be fully elucidated, these studies have unearthed a plethora of compromised intracellular processes and pathways affecting motor neuron health, involving defective RNA processing [18], impaired oxidative stress regulation and mitochondrial function [19,20], irregularities in cytoskeletal structure affecting axonal transport [21,22], reduced intracellular $\mathrm{Ca}^{2+}$ handling capacity [23-25], or compromised energy metabolism [26]. None of which, however, has yet resulted in the development of an effective treatment strategy. ALS research in the past decades was strongly centered on the investigation of lower motor neurons in the spinal cord, while upper motor neuron pathology is understudied. A large body of evidence, however, emphasizes the cardinal role of the motor cortex in triggering UMN and LMN degeneration. As such, cortical hyperexcitability has been demonstrated in ALS patients and even asymptomatic ALS mutation carriers [27], but the molecular, cellular, and network mechanisms underlying cortical hyperexcitability are not completely understood. Both cell autonomous (e.g., altered intrinsic excitability of UMN) and non-cell autonomous mechanisms (e.g., alterations in the local microcircuitry caused by cells other than UMN, such as glia) are conceivable (for detailed review, see Gunes et al. [28]). In this review, we will summarize recent evidence for cortical hyperexcitability in both humans and rodent models of ALS and recapitulate the currently known underlying cellular and circuit mechanisms.

\section{Clinical Evidence for Cortical Hyperexcitability in ALS}

The site of origin of the disease has long been a matter of debate. While some believe the initial pathology occurs at the level of lower motor neurons (LMN) in the spinal cord or even the neuro-muscular junction [29,30], with the cortex and UMN being affected in a retrograde process (termed 'dying-back hypothesis'), others argue that the disease originates in the cortex and propagates in a corticofugal manner to subsequently affect LMN in the spinal cord [30,31]. The latter process was coined the 'dying-forward' hypothesis [31]. Several lines of evidence in fact strongly argue for a cortical origin of ALS [32,33]. These encompass the spreading pattern of the typical TDP-43 pathology, following anatomical connections through axonal projections and synaptic contacts [32]. Most importantly, electrophysiological measurements have revealed that cortical hyperexcitability is present in both sporadic and familial ALS patients and can occur even prior to disease onset in familial ALS cases [34-36]. Cortical hyperexcitability can be clinically assessed by means of threshold tracking paired-pulse transcranial magnetic stimulation (TMS) combined with motor-evoked potential (MEP) measurements (e.g., of the M. abductor pollicis brevis), as well as via electroencephalography (EEG) or functional MRI (fMRI) [37-42].

A number of parameters can be assessed to probe differences in cortical excitability when performing TMS, such as the resting motor threshold (RMT) and the MEP amplitude [43]. RMT represents the minimal stimulus intensity needed to excite the corresponding muscle [44] and was found to be decreased early in the disease, thereby reflecting UMN hyperexcitability $[45,46]$. In late-stage ALS patients, however, the RMT was increased along with a decrease in the MEP amplitude, indicative of gross denervation [47,48]. Cortical hyperexcitability could in principle result from either increased excitation or compromised intracortical inhibition. To disentangle both options, paired-pulse stimulation protocols can be applied, in which the interstimulus interval (ISI) determines the magnitude of the MEP. While very short ISIs (1-7 ms) depress the MEP, longer ISI (10-30 ms) can facilitate the MEP [36]. The degree of inhibition or facilitation can be assessed by altering the stimulus intensity of the 2nd pulse, the difference of which is represented in the short/long intracortical inhibition (SICI/LICI) and the intracortical facilitation (ICF) metric [36,38] 
(Figure 1a-c). In ALS patients, the SICI was shown to be reduced [36,49-55] (Figure 1b), also in patients with subclinical UMN damage [56], indicating compromised $\mathrm{GABA}_{\mathrm{B}}$ receptor mediated intracortical inhibition [57]. On the other hand, cortical facilitation was strongly increased, arguing for an elevated excitation [36,58-61] (Figure 1c). The phenomena of cortical hyperexcitability thus can be explained by a combined increase in excitation and impaired inhibition.

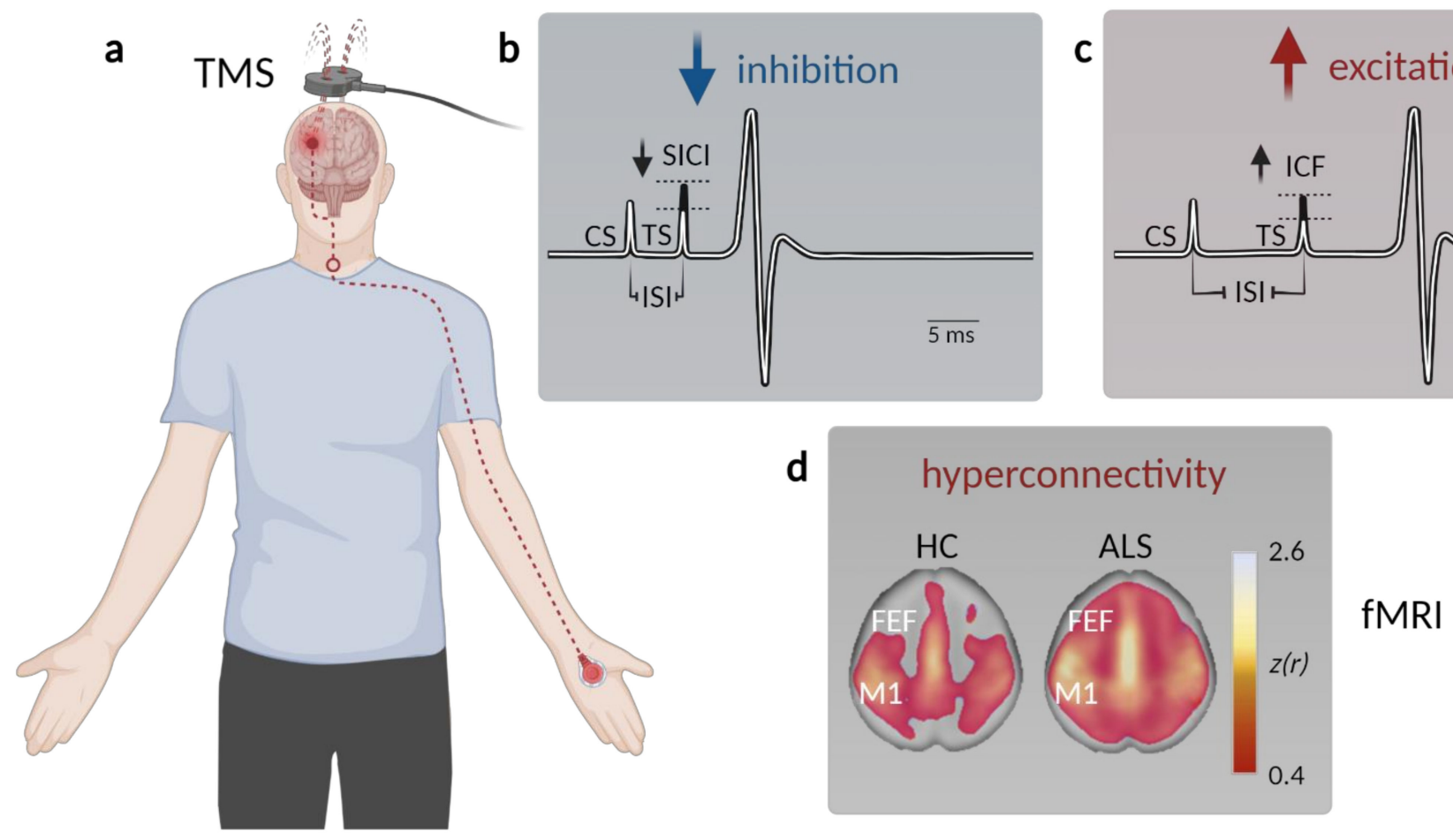

Figure 1. Assessment of motor cortex hyperexcitability and hyperconnectivity in ALS patients. (a) Schematic displaying paired-pulse transcranial magnetic stimulation (TMS) in patients. A magnetic coil is placed above the primary motor cortex (M1), and the resulting motor-evoked potential (MEP) is measured at the innervated muscle (typically the M. abductor pollicis brevis). (b) Example MEP depicting muscle potential changes (black-healthy controls, HC; white-ALS) triggered by a short interstimulus interval (ISI) between the conditioned stimulus (CS) and the test stimulus (TS) to facilitate short-interval intracortical inhibition (SICI). The TS needed to evoke a similar MEP is reduced in ALS, indicative of compromised intracortical inhibition. (c) To probe intracortical facilitation (ICF), the TS is applied after a longer ISI, which typically elicits a stronger MEP response compared to a single stimulus. The TS intensity needed to evoke a similar MEP observed after pair-pulse stimulation in healthy controls is reduced in ALS patients, arguing for elevated excitation within M1. (d) Functional magnetic resonance imaging (fMRI) studies demonstrate enhanced connectivity in somatosensory networks, as well as across (pre)frontal areas (FEF, frontal eye field) in ALS patients (data from Schulthess et al. [27], modified and used with permission of the authors and the publisher).

In addition to TMS, EEG is widely used to assess cortical excitability by measuring parameters such as event-related desynchronization/synchronization (ERD/ERS), enabling higher temporal resolution compared to TMS. ERD typically represents a correlate of an activated cortical network prior to the execution of a motor task [62], whereas ERS indicates an active inhibitory process of the cortical network after the motor task is performed [62]. In support of the notion of cortical hyperexcitability, ALS patients exhibit lower ERS, whereas task-dependent ERD is either decreased-likely reflecting UMN loss during later disease stages-or not significantly altered between ALS-patients and healthy controls [63,64]. These findings can be explained by both increased excitability of UMN and compromised intracortical inhibition during rest and motor task execution $[46,61,65]$. Corroborating EEG findings, a magnetoencephalography (MEG) study by Proudfoot et al. showed that 
ALS patients have an enhanced cortical beta desynchronization during a visually cued lateralized motor task [66].

Although limited in number, functional magnetic resonance imaging (fMRI) investigations were also employed in clinical ALS studies. fMRI is a widely used imaging technique that detects changes in blood oxygenation in the brain as a proxy for neuronal activity in the respective region $[67,68]$. Multiple studies reported a stronger response to a motor task in ALS patients compared to healthy subjects [69-71]. Resting state fMRI also revealed an increased functional connectivity of the motor cortex not only within the sensorimotor network [72,73] and the prefrontal association cortex [74], but also within the brainstem, ventral attention, and default mode network in sALS patients [27,75] (Figure 1d). Interestingly, changes in functional connectivity between the cerebellum and a network comprised of the precuneus, the cingulate, and the middle frontal lobe were already observed in presymptomatic mutation carriers [39].

The electrophysiological findings of compromised intracortical inhibition were further substantiated by proton magnetic resonance spectroscopy $\left(1^{\mathrm{H}}-\mathrm{MRS}\right)$ measurements, revealing reduced GABA levels in ALS patients [76] and demonstrated a reduction of glutamate-glutamine levels upon riluzole treatment [77]. Additional histological and transcriptomic analyses demonstrated decreased $\mathrm{GABA}_{\mathrm{A}}$ receptor densities and a downregulation of the $\alpha 1$-subunit and upregulation of $\beta 1$-subunit mRNA levels in the post-mortem motor cortex of ALS patients [78]. Furthermore, a downregulation of N-methyl-D-aspartate receptors (NMDAR) and alterations in the expression of particular $\alpha$-amino-3-hydroxy5-methyl-4-isoxazolepropionic acid receptor (AMPAR) subunits in ALS were revealed by immunohistochemistry and RT-PCR [79]. These investigations, however, were conducted in post-mortem tissue, and thus reflect end-stage alterations.

Taken together, electrophysiological and imaging studies have revealed an early increase in cortical excitability in ALS, which is likely based on a combined increase in excitation and a decrease in inhibition.

\section{Human-Derived Induced Pluripotent Stem Cells to Study Altered Motor Neuron Excitability in ALS}

Patient-derived induced pluripotent stem cells (iPSCs) have emerged as a powerful tool to study the molecular and cellular mechanisms of neurological diseases. The method has also been widely used in ALS research. However, the majority of studies thus far have again focused on the investigation of iPSC-derived spinal motor neurons, while only limited information on cortical neurons, or more specifically upper motor neurons, is currently available [80]. Electrophysiological recordings conducted on iPSC-derived LMN cultures revealed somewhat conflicting results. While early (2-4 weeks old) cultures harboring SOD1, C9orfF72, or TARDBP mutations displayed hyperexcitability and increased spontaneous activity levels [81,82], prolonged culture renders these ALS LMN hypoactive, such that after 7-10 weeks reduced spontaneous activity and decreased F-I gain was detected in conjunction with fewer synaptic inputs [82]. Indeed, hypoexcitability and/or hypoactvitiy of LMNs has been reported by others in iPSC-derived LMNs harboring a C9orf72 repeat expansion measured at 9-10 weeks in culture [83], in four-week-old SOD1 mutation LMN cultures [84]; and in seven-week-old LMN cultures from FUS and SOD1 mutation carriers [85]. A caveat of these studies, however, is the incomplete functional characterization and motor neuron subtype classification of the investigated LMNs. It is well established that LMN subtypes differ in their vulnerability in ALS [86], an effect that is insufficiently modelled in iPSC-derived LMN cultures to date and thus further complicates the interpretation of the data. In contrast to the many studies conducted on iPSC-derived spinal motor neurons, very few reports have so far addressed the excitability alterations of cortical neurons. Recently, Perkins et al. found that iPSC-derived cortical neurons harboring C9orf72 repeat expansions display enhanced network burst activity and increased synaptic inputs when cultured for 4-6 weeks, corroborating the cortical hyperexcitability seen in patients (Figure 1d, Perkins et al. [87]). Again, cell type specificity 
was not further characterized in this study. Though informative, cell culture models come with inherent limitations, such as the absence of a tightly regulated network consisting of intricately connected diverse types of neurons and glia cells, as well as the rather short lifetime of those cells studied. Recent advances in the field have led to the development of more complex systems, such as brain organoid slice cultures [88] or even human 3D cortico-motor assembloids that recapitulate the complete cortico-spinal-muscle circuit [89]. These latest advancements are promising and will be instrumental for future research into the circuit mechanisms involved in ALS as well as other neurodegenerative diseases.

\section{Evidence for Cortical Hyperexcitability in ALS Rodent Models}

Mouse models offer the great advantage of direct experimental access to individual, characterized elements of the motor cortex circuitry, which enables an in-depth molecular and cellular investigation across disease-stages. Numerous rodent models have been thus generated in the past, based on the genetic mutations identified in fALS patients. However, the investigation of UMN or cortical dysfunction is clearly underrepresented in mouse studies, largely due to the fact that UMN seem less affected in mice vs. humans, and importantly, the direct monosynaptic connection of UMN and LMN is lacking in rodents. Recent studies now demonstrate that UMN dysfunction is also present in rodent models and shares features of the human pathology. As such, there is also evidence for cortical hyperexcitability in mouse models of ALS, akin to the human disease (for review, see Gunes et al. [28]). Most critically, a recent study now demonstrates that cortical hyperactivity is sufficient to drive LMN degeneration, even in the absence of a genetic mutation [90]. In their study Haidar et al. used a chemogenetic approach to chronically drive neurons in motor cortex, which caused UMN loss, corticospinal tract degeneration, and gliosis, and importantly also caused the degeneration of LMN and the neuromuscular junction resulting in impaired motor function [90]. This seminal work therefore not only strongly supports the corticofugal origin of ALS, but also for the first time demonstrates that neuronal hyperactivity alone is sufficient to cause downstream degeneration.

What are the mechanisms leading to early cortical hyperexcitability? Alterations in the net motor cortex excitability can be driven by intrinsic (cell-autonomous) mechanisms, affecting the main motor cortex output population-the UMN (e.g., synaptic deficits caused by altered neurotransmitter receptor expression levels and alterations in active/passive membrane properties caused by deficits in voltage gated channels, etc.) —and/or by extrinsic (non-cell autonomous) mechanisms, inflicted by cells other than UMN, such as altered glutamatergic or GABAergic neurons or glia cells. It has already become obvious from TMS and electrophysiological studies that cortical hyperexcitability in ALS patients is based on a combination of events and likely involves the dysfunction of multiple cell types within and beyond the primary motor cortex (M1).

\section{Circuit Mechanisms Involved in Cortical Hyperexcitability}

The M1 microcircuit consists of excitatory pyramidal neurons (PN) and local inhibitory interneurons (Figure 2a). Depending on their projection target, PN can be further categorized into intratelencephalic (IT) and pyramidal tract neurons (PT, aka UMN, also known as corticospinal motor neurons (CSMN) or corticospinal tract (CST) neurons and Betz cells in humans). IT neurons are found in layer $2 / 3,5$, and 6 , with corticocortical (CC) neurons projecting transcallosally and corticostriatal (CStr) neurons projecting to the striatum. UMN are embedded in layer 5B of M1 (Figure 2a). They are multi-projectional, and downstream target regions include both the ipsi- and contra-lateral brainstem and the spinal cord, with branches also innervating the ipsilateral cortex and some subcortical regions [91]. The strongest feedforward excitatory drive to layer 5 neurons is provided by layer $2 / 3 \mathrm{PN}$ (Figure 2a), followed by intralaminar projections within layer 5 . Activity levels and information processing in M1 is regulated by a diverse set of local and remote inhibitory neurons, which constitute $\sim 20 \%$ of the cortical neuronal population [92,93]. Based on the expression of typical markers, three major non-overlapping subtypes of interneurons are 
known: parvalbumin (PV), somatostatin (SST), and 5-HT3a (with the majority of them being vasoactive intestinal peptide (VIP)) expressing interneurons [94-96] (Figure 2a). While PV and SST target PN directly at the level of their somata (PV) and the dendritic compartment (SST), respectively, VIP regulate the circuit via disinhibition, i.e., by inhibiting PV and SST. Notably, SST are also inhibiting PV to allow for further fine-tuning of information processing within neural circuits [97,98]. Glutamatergic (excitatory) and GABAergic (inhibitory) neurons in the M1 circuitry are further regulated by neuromodulatory inputs [91,99-101]. Several circuit elements were shown to be structurally and functionally altered in various models of the disease (Figure 2b, Gunes et al. [28]), causing a disruption of the tightly controlled excitation/inhibition balance in M1:

a

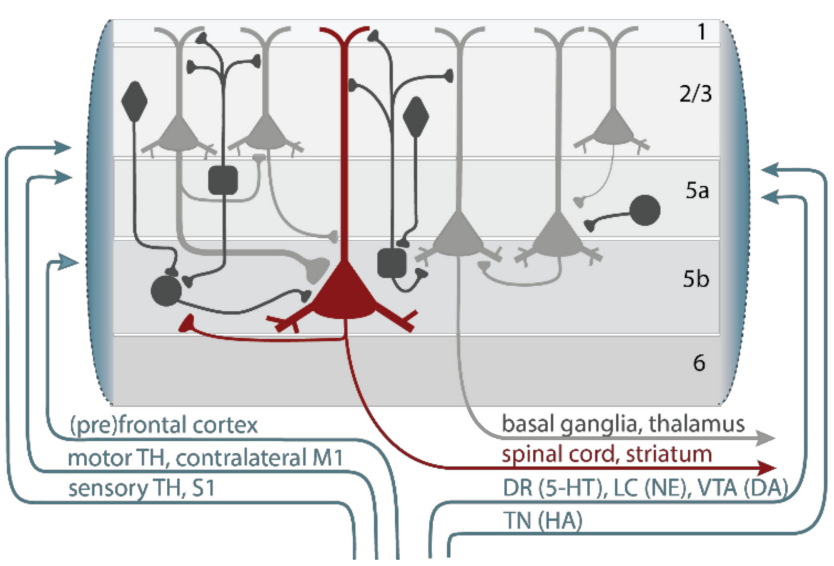

b

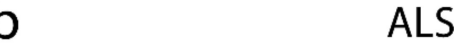

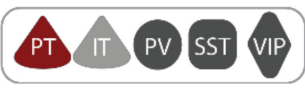

Figure 2. Alterations of primary motor cortex (M1) microcircuit elements in ALS. (a) In the healthy M1 microcircuitry upper motor neurons (UMNs), aka, pyramidal tract neurons (PT, red), located within cortical layer $5 \mathrm{~b}$ receive feedforward excitatory synaptic input primarily from intratelencephalic (IT, light gray) neurons in layer 2-3 and, to a lesser degree, intralaminarly from layer 5 IT. Longrange feedforward input is provided by the (pre)frontal and somatosensory cortex, the contralateral primary motor cortex (M1), and the thalamus (TH). Excitation is controlled by a number of inhibitory GABAergic interneurons, which express either parvalbumin (PV), somatostatin (SST), or vasoactive intestine peptide (VIP) (dark gray). Neuromodulatory input further shapes information processing in M1 and is provided by projections from the locus coeruleus (LC; releasing norepinephrine (NE)), the ventral tegmental area (VTA; releasing dopamine (DA)), the dorsal raphe (DR; releasing serotonin (5-HT)), or the tuberomammillary nucleus (TN; releasing histamine (HA)). (b) In ALS, hypoactive PV and hyperactive SST interneurons were reported, as well as increased long-range feedforward excitatory synaptic inputs and elevated functional connectivity, while neuromodulatory inputs were found to be compromised. Line thickness reflects connectivity strength.

\subsection{Alterations of Upper Motor Neurons}

Naturally, UMN have been the center of attention when it comes to studying M1 pathology in ALS. These studies revealed structural abnormalities, which, however, seemingly differ between mouse models: While, in SOD1 ${ }^{\mathrm{G} 93 \mathrm{~A}}$ transgenic ( $\mathrm{tg}$ ) mice, a reduction of dendritic spine density (the structural correlates of excitatory synapses) along with a reduced cell complexity (fewer dendrites) were observed [102,103], an increase in apical and basal dendritic spine densities in TDP43 ${ }^{\mathrm{Q} 331 \mathrm{~K}} \mathrm{tg}$ mice was found [104]. Functionally, UMNs were shown to be hyperexcitable across various ALS mouse models. In the SOD1 G93A mouse model layer, 5 PNs (which largely comprise UMN) display age- and disease-stage specific alterations in their intrinsic properties. Already in neonatal tg mice (P5-6), UMNs are hyperexcitable, followed by a normalization during pre-symptomatic stages (P14-P70), 
but there is a reoccurrence of hyperexcitability during symptomatic stages $(\geq P 90)[105,106]$. However, in contrast others also reported UMN hypoexcitability during the early symptomatic phase [107]. Similar findings were made in the TDP- $43^{\mathrm{A} 315 \mathrm{~T}}$ mouse model, in which layer 5 PN displayed a higher firing frequency during the pre-symptomatic stage [2,104]. In agreement with these studies, 30 days of induced expression of TDP- $43^{\Delta N L S}$ in adult mice also lead to intrinsic hyperexcitability in M1 layer 5 PN, highlighting the role of TDP-43 cytoplasmic mislocalization in driving cortical hyperexcitability [108]. Furthermore, also in the wobbler mouse model of ALS, which is based on a spontaneous mutation in the VPS54 gene in the C57BL/Fa strain [109], layer 5 PN are hyperexcitable, as shown by an increased input resistance and strongly reduced current threshold (the minimal injected current needed to elicit an action potential) [110].

\subsection{Increased Excitatory Inputs to UMNs}

In addition to intrinsic alterations of UMNs, there is also evidence for an augmented synaptic input onto them, witnessed as increased miniature excitatory synaptic current (mEPSC) frequencies in UMNs in presymptomatic SOD1 ${ }^{\mathrm{G} 93 \mathrm{~A}}$ [103] and in TDP-43 ${ }^{\mathrm{Q} 331 \mathrm{~K}} \mathrm{tg}$ mice [104]. The source of these excitatory synaptic inputs remains elusive. Based on the microcircuit connectivity, the main input source for layer 5 PN (UMNs) are layer 2/3 PN. Notably, layer 2/3 PN are also hyperexcitable in the SOD1 ${ }^{\mathrm{G} 93 \mathrm{~A}}$ model [105] and more active in the FUS ${ }^{\triangle N L S}$ mouse model, as witnessed by increased spontaneous activity [111], further supporting the notion of excess excitatory drive onto UMNs. Additional excess synaptic inputs might also result from long-range projections. Indeed, connectivity changes were reported in SOD1 ${ }^{\mathrm{G} 93 \mathrm{~A}}$ mice [74], with increased synaptic inputs from $\mathrm{S} 1$ and contralateral M2 already during early-symptomatic stages, which further expanded to include the thalamus, contralateral M1, auditory cortex, and caudoputamen at later stages of the disease (Figure 2b, Commisso et al. [74].

\subsection{Reduced Cortical Inhibition}

Excitation/inhibition (E/I) imbalance can be caused by increased excitation as well as compromised inhibition. In addition to enhanced intrinsic excitability and excitatory inputs onto UMNs, several lines of evidence highlight a parallel reduction in synaptic inhibition in M1 in various mouse models of the disease. Impaired inhibition was evident by reduced inhibitory postsynaptic currents (IPSCs) in UMNs in SOD1 ${ }^{\mathrm{G} 93 \mathrm{~A}}$ [112], TDP$43^{\mathrm{A} 315 \mathrm{~T}}$ mice [2] and in the wobbler mouse model [110], which could be based on a loss of interneurons or particularly inhibitory synapses and/or functional interneuronal deficits. Indeed, our recent work in the FUS ${ }^{\triangle N L S}$ model suggests that primarily inhibitory synapses are affected and less abundant, while overall PV interneuron number was not significantly altered [111]. There are contradictory findings regarding the density of subtype-specific interneurons in SOD1 ${ }^{\mathrm{G} 93 \mathrm{~A}}$ mice. While some have reported no change in the density of PV-, SST-, or VIP- expressing interneurons [113,114], others observed a decrease [112]. In the wobbler mouse model, the density of PV and SST interneurons was decreased [110]. Functionally, mouse-line and disease-stage specific alterations of interneuron subtypes were also identified. In SOD1 ${ }^{\mathrm{G} 93 \mathrm{~A}}$ mice, whole-cell recordings of PV interneurons revealed variable changes throughout the course of the disease [105]. While the excitability of PV interneurons was not altered presymptomatically, they turned hyperexcitable during the symptomatic stage (P90-101) [105]. Others, however, have reported hypoexcitability of $\mathrm{PV}$ interneurons in presymptomatic SOD1 ${ }^{\mathrm{G} 93 \mathrm{~A}}$ mice [112] (Figure 2b). Notably, in TDP$43^{\mathrm{A} 315 \mathrm{~T}}$ mice Zhang et al. observed hyperactive SST, which suppressed PV activity, thus causing layer $5 \mathrm{PN}$ disinhibition [2] (Figure 2b). Importantly, means to restore PV activity levels in the motor cortex either by ablating hyperactive SST in TDP-43 ${ }^{\mathrm{A} 315 \mathrm{~T}}$ mice [2] or through direct chemogenetic stimulation of $\mathrm{PV}$ in $\mathrm{SOD} 1{ }^{\mathrm{G} 93 \mathrm{~A}}$ mice [112] restored layer $5 \mathrm{PN}$ excitability and firing rates [2,112], further emphasizing the role of interneurons in cortical ALS pathophysiology. 


\subsection{Altered Neuromodulation}

In addition to glutamatergic and GABAergic inputs, neuronal activity levels are furthermore regulated by a number of neuromodulators, which also seem to be altered in ALS patients and mouse models of the disease [115]. These alterations affect the dopaminergic system, as evidenced by compromised dopaminergic signaling in the striatum in ALS patients [116,117], a finding that is corroborated by mouse studies, in which SOD1 ${ }^{\mathrm{G} 1 \mathrm{H}}$ mice display a reduction of dopamine levels and the loss of dopaminergic neurons (Figure $2 b$, Kostic et al. [118]). Moreover, serotonin levels were also found to be affected. In ALS patients, a loss of serotonergic neurons in the brainstem was reported, and also in SOD1 G86R mice reduced levels of serotonin in the brainstem and spinal cord were observed [119]. For a more detailed description of neuromodulatory disturbances, please see this excellent review [115].

\section{A Potential Role of Astrocytes in Cortical Hyperexcitability}

Another key player in cortical and spinal motor circuits, regulating synaptic efficacy and information processing, are astrocytes. Astrocytes serve numerous physiological functions such as the regulation of neurotransmitter concentration in the synaptic cleft, the maintenance of ion homeostasis, and the supply of energy substrates to neurons, through which they modulate energy metabolism [120,121]. Several molecular alterations of astrocytes were identified in ALS patients, presumably compromising the maintenance of neurotransmitter and ion homeostasis in the parenchyma [122,123]. A large part of the existing literature on the causal involvement of astrocytes in ALS is based on studies conducted in spinal cord preparations or cultured spinal motor neurons [124-127]. Whether these observations are also applicable to cortical astrocytes in the disease remains to be clarified. The most extensively studied molecular alteration is a reduced expression of the astrocytic excitatory amino acid transporter 2 (EAAT2, Figure 3). Its downregulation was identified in both the spinal cord of SOD1 ${ }^{\text {G85R }}$ and SOD1 ${ }^{\text {G93A }}$ and in the amyotrophic lateral sclerosis-parkinsonism-dementia complex (ALS-PDC) mouse model [124-127], as well as in the motor cortex and spinal cord of late-stage ALS patients [122,126,128], potentially exposing neurons to glutamate-mediated excitotoxicity. This mechanism is also shared by multiple neurodegenerative diseases [129-131]. Furthermore, impaired extracellular potassium clearance, due to a reduced expression of the astrocytic inward-rectifying (Kir4.1) channel and a dysregulation of $\mathrm{Na}^{+} / \mathrm{K}^{+}$ATPases were reported in both SOD1 G93A tg rats (cortex) [132] and SOD1 ${ }^{\text {G93A }}$ tg mice (spinal cord) [133], a finding, which was also observed in iPSC-derived astrocytes from ALS patients (SOD1 mutation carriers) $[123,133,134]$ (Figure 3). In addition to maintaining ion homeostasis in the brain, astrocytes also provide neuronal energy substrates, such as lactate $[135,136]$. Lactate is largely produced in astrocytes through glycolysis and glycogenolysis and is exported to the extracellular space through monocarboxylate transporters (MCTs), where it is taken up by neurons through MCTs (Figure 3). Interestingly, lactate was also shown to modulate neuronal activity levels and plasticity [135], rendering it an important molecule potentially involved in alterations of the motor neuron circuitry in ALS. Notably, reduced lactate levels were detected in the motor cortex of SOD1 ${ }^{\mathrm{G} 93 \mathrm{~A}} \mathrm{tg}$ mice by in vivo ${ }^{1} \mathrm{H}$ magnetic resonance spectroscopy $\left({ }^{1} \mathrm{H}\right.$ MRS) already during the early symptomatic phase $[135,137,138]$, as well as in a SOD1G93A $\operatorname{tg}$ astrocyte-MN (wt) co-culture system (Figure 3, Madji Hounoum et al. [139]). 


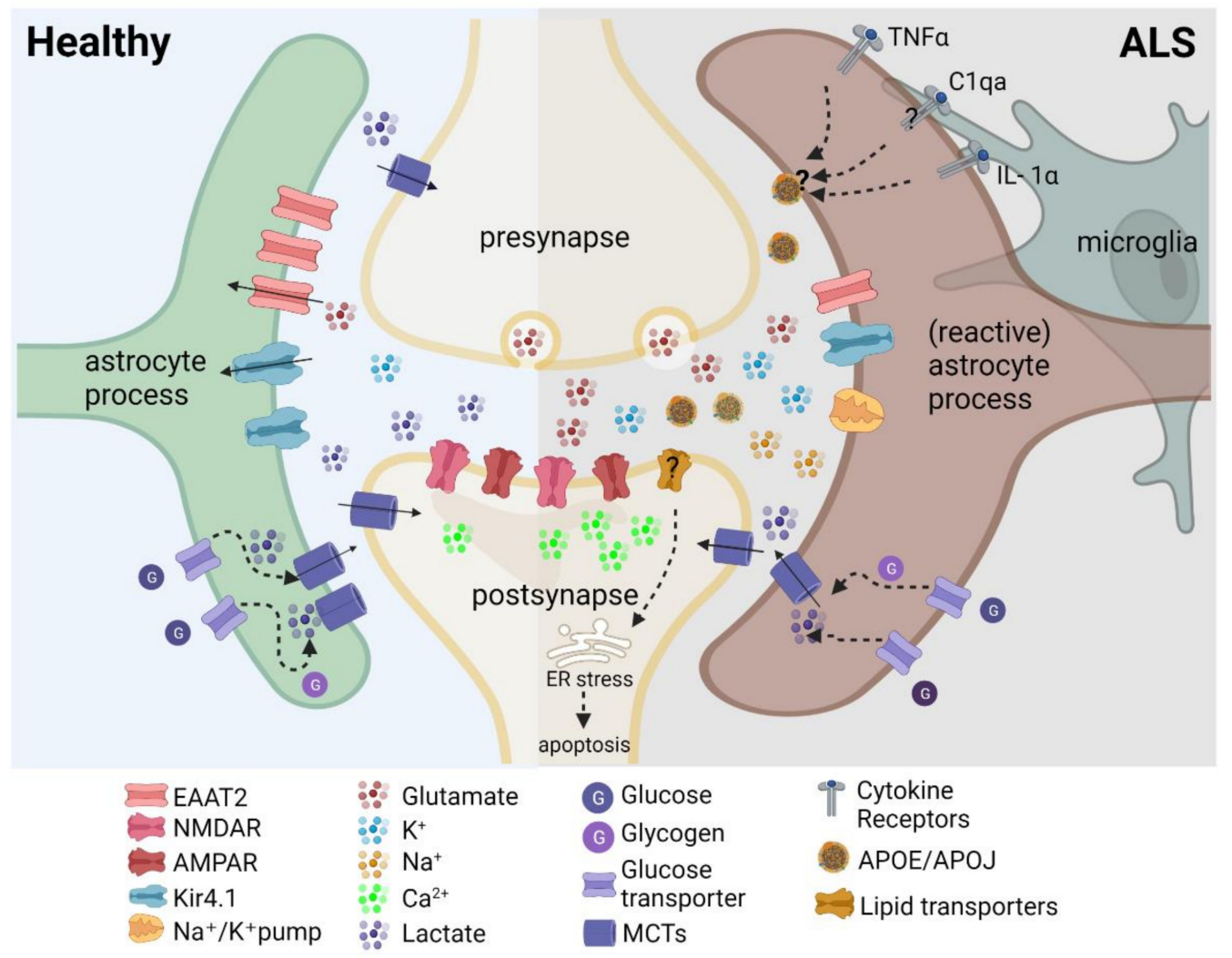

Figure 3. Altered molecular profile of astrocytes in ALS. The downregulation of astrocytic excitatory amino acid transporter 2 (EAAT2) could cause increased synaptic glutamate and postsynaptic $\alpha$ amino-3-hydroxy-5-methyl-4-isoxazolepropionic acid receptor (AMPAR) and N-methyl-D-aspartate receptor (NMDAR) activation and increased $\mathrm{Ca}^{2+}$ levels. Reduced expression of the inward rectifier potassium channel (Kir4.1) disrupts $\mathrm{K}^{+}$homeostasis, resulting in excess $\mathrm{K}^{+}$in the synaptic cleft. Reduced extracellular lactate levels might affect neuronal energy supply and alter activity levels and plasticity. Reactive astrocytes are induced by microglia secreting inflammatory cytokines interleukin 1 alpha (IL- $1 \alpha$ ), tumor necrosis factor (TNF- $\alpha$ ), and the complement component 1 , subcomponent $q$ (C1q)). Saturated lipids in apolipoprotein E (APOE), and apolipoprotein J (APOJ) lipoparticles were identified as the toxic factors secreted by reactive astrocytes, triggering lipoapoptosis.

In addition to the altered physiological function of astrocytes in ALS, there is intriguing evidence suggesting that astrocytes secrete neurotoxic factors, causing motor neuron $(\mathrm{MN})$ degeneration and death $[140,141]$. Most studies are based on in vitro experiments, in which cultured primary LMN are exposed to media obtained from cultured ALS transgenic astrocytes or co-culture systems of astrocyte-MN [140-144]. MN bathed in astrocytic conditioned media obtained from SOD1 ${ }^{\mathrm{G} 93 \mathrm{~A}}$ mice or co-cultured with IPSCderived astrocytes from patients positive for the C9orf72 repeat expansion display acute hyperexcitability with increased voltage-gated $\mathrm{Na}^{+}$currents and repetitive firing prior to MN death $[143,145]$. Earlier work had already identified a highly proliferative subtype of cultured astrocytes obtained from SOD1 ${ }^{\mathrm{G} 93 \mathrm{~A}} \mathrm{tg}$ rats, which seemingly secreted toxic factors [146]. In line with this, more recent work also demonstrates that reactive astrocytes can secrete toxic factors $[147,148]$. In an attempt to prevent the formation of reactive astrocytes, Guttenplan et al. crossed SOD1 ${ }^{\mathrm{G} 93 \mathrm{~A}} \mathrm{tg}$ mice with a triple knockout mouse, lacking IL- $1 \alpha, \mathrm{TNF} \alpha$, and C1qa [148]. Those three factors are released by microglia and induce the formation of reactive astrocytes [147]. The lack of those three factors strongly slowed down disease progression, thereby yielding the longest lifespan prolongation 
hitherto observed in the SOD1 ${ }^{\mathrm{G} 93 \mathrm{~A}}$ tg model [148]. In their new study, Guttenplan et al. succeeded in narrowing down the involved toxic factors released by reactive astrocytes and surprisingly identified saturated lipids found in apoliprotein E (APOE) and apoliprotein J (APOJ) lipoparticles [144]. These lipoparticles might be taken up by neurons through lipid transporters or ApoE particles to cause lipoapoptosis (Figure 3, Smolič et al. [149]). Whether these pathways are also causally involved in the degeneration of UMN and LMN in ALS remains to be determined. It also remains open whether astrocyte reactivity and the corresponding secretome represent a unifying process shared by different forms of the disease, because recent evidence suggests a mutation specific molecular heterogeneity of reactive astrocytes in ALS [150]. These exciting recent data will surely spur future studies, shedding more light onto the molecular mechanisms by which astrocytes compromise cortical and spinal circuits in ALS.

\section{Implications for Potential Circuit-Level Based Therapeutic Strategies}

Unfortunately, despite the profound insight into the molecular mechanisms causing motor neuron degeneration in ALS an efficient treatment or cure for this devastating disease is still lacking. To date, riluzole, which blocks glutamate release and neurotransmission [151], is (in addition to edaravone) the only FDA-approved drug for the treatment of ALS. However, the beneficial effect on the survival of ALS patients is unfortunately minimal and varies between patients [152-154]. The effects in mouse models are also variable, ranging from no effect on disease onset and survival to a modest prolongation of life expectancy (for review see [155-157]). Notably, little is known about the effect of riluzole at the circuit level in the cortex and spinal cord or whether potential adaptive (homeostatic) mechanisms upon chronic treatment might exist. Since riluzole indiscriminately affects glutamatergic neurotransmission, it might also compromise activity levels of inhibitory interneurons in vivo. The net effect on the circuitry in vivo thus still remains elusive. In light of previous reports emphasizing the involvement of interneurons in the development of cortical hyperexcitability in ALS, a more targeted approach to interfere with dedicated circuit elements is thus strongly desirable. Owing to the recent impressive advancements in chemogenetic approaches and adeno-associated virus (AAV)-mediated gene therapy, circuit-level therapy in humans has now come within reach. To target specific cell types in the motor circuitry, chemogenetic tools such as Designer Receptors Exclusively Activated by Designer Drugs (DREADDs) and Pharmacologically Selective Effector Molecules (PSEMs)/Pharmacologically Selective Actuator Modules (PSAMs) systems have been successfully used in mice [112]. PV-expressing interneurons were chronically activated in $\mathrm{SOD} 1^{\mathrm{G} 93 \mathrm{~A}} \mathrm{tg}$ mice during the pre-symptomatic and symptomatic stages via DREADDs and the application of its ligand clozapine-n-oxide $(\mathrm{CNO})$, which delayed the development of motor deficits [112]. In humans, AAV-mediated gene therapy has already been approved by the FDA for the treatment of diseases such as lipoprotein lipase deficiency or spinal muscular atrophy, and many more clinical trials to combat various diseases are under way [158-160]. While we still largely lack long-term data to fully evaluate the efficacy and potential side-effects, the first clinical trials are overall extremely promising. However, to date, genetic means to manipulate the excitability of neurons in humans have never been tested. Thus, in addition to the already acknowledged risks of mutagenesis, haemato-, hepato- and neurotoxicity, one further needs to establish the application of chemogenetic tools, including the optimal stimulation paradigm and the development of highly selective agonists. Cell type specificity could be achieved by a combination of AAV serotypes and/or promoters and enhancers, such as, for inhibitory neurons, the $m D l x$ [161] or a novel GAD65 promoter [162]. The newest generations of AAVs now also enable brain-wide transgene expression in non-human primates, while causing less liver toxicity [163], thereby further enlarging the toolbox. Based on previous mouse studies, one can picture future therapeutic approaches based on the selective modulation of interneurons (PV, SST), UMNs themselves (potentially also targeted retrogradely, Genç et al. [164]), and astrocytes. 
A modified CRISPR-based gene editing method involving an intein-mediated transsplicing system that enables single-base editing of SOD1 has overcome the transient therapeutic effect of antisense oligonucleotides (ASOs) and RNA interference (RNAi)-based gene therapy and achieved a permanent knock down of mutant SOD1 expression in vivo [165]. The group employed the intrathecal delivery of dual AAV9 particles into the spinal cord to interfere with the expression of SOD, which resulted in a predominant targeting of astrocytes and led to a $40 \%$ reduction in intracellular SOD1 inclusions, preserved neuromuscular function, and a prolonged life expectancy [165]. Alternatively, transplantation studies are also conceivable with the aim of replenishing the circuitry with healthy astrocytes. Indeed, several astrocyte transplantation therapies have entered phase I/IIa clinical studies (ClinicalTrials.gov: ID-NCT03482050; ID-NCT02943850; ID-NCT02478450), in which healthy astrocytes derived from human embryonic stem cell or human neural progenitor cells expressing glial cell-derived neurotrophic factor (GDNF) are transplanted. Multiple studies in ALS rodent models have demonstrated the therapeutic potential of this astrocyte-based cell transplantation/replacement approach in delaying disease onset and slowing down disease progression [166-169]. However, as we still lack long-term data, one needs to be cautious and carefully monitor possible side-effects, such as a potential gain of toxic neuroinflammatory properties of transplanted astrocytes [170]. Overall, these recent approaches hold great promise for the development of targeted, cell type specific interventions, which will hopefully lead to a much-needed clinical breakthrough.

\section{Concluding Remarks}

We here have summarized electrophysiological findings from both ALS patients and mouse models of the disease, demonstrating strong evidence for cortical hyperexcitability in ALS. We disentangle the underlying cellular and circuit mechanisms and discuss recent data showing, for the first time, a clear link between cortical hyperactivation and subsequent downstream MN degeneration and loss in the spinal cord. Together these data provide compelling evidence for a cortical origin and a consecutive corticofugal trajectory of the disease. We also review reports that suggest cortical hyperexcitability is a consequence of a combination of cell-autonomously elevated UMN excitability and increased excitatory inputs, paralleled by compromised inhibition. The resulting imbalance in excitation and inhibition is notably a feature shared by various other neurodegenerative diseases such as Alzheimer's disease [171-174], Huntington's disease [175], multiple sclerosis [176], Parkinson's disease $[177,178]$, and spinal muscular atrophy [179], as well as psychiatric diseases such as schizophrenia [180] and even glioblastoma [181]. The underlying circuit mechanisms causing E/I imbalance in dedicated areas of the brain likely differ between these disorders, as does its role for the neurodegenerative process typical of those diseases. However, these recent findings open up new avenues for promising therapeutic strategies based on precise circuit-level interventions, which could, for instance, be achieved through adeno-associated viral vectors. To this end, however, more detailed insight into the cell-type specific alterations in the human cortex is still needed.

Author Contributions: All authors contributed to the conceptualization, writing, visualization, review and editing of the manuscript. Supervision, project administration and funding acquisition: S.L. All authors have read and agreed to the published version of the manuscript.

Funding: This work was supported by the Deutsche Forschungsgemeinschaft (DFG, German Research Foundation) under Germany's Excellence Strategy within the framework of the Munich Cluster for Systems Neurology-EXC 2145 SyNergy-ID 390857198 (SL), the Emmy Noether Programme (SL), the Deutsche Gesellschaft für Muskelkranke (SL), the European Union's Horizon 2020 research and innovation programme under the Marie Skłodowska-Curie grant agreement No 860035 (SL, SJ), and the Graduate School for Systemic Neurosciences GSN-LMU (ZG, VK, SJ).

Acknowledgments: Figures 1 and 3 were created with BioRender.com.

Conflicts of Interest: The authors declare no conflict of interest. 


\section{References}

1. Kiernan, M.C.; Vucic, S.; Cheah, B.C.; Turner, M.R.; Eisen, A.; Hardiman, O.; Burrell, J.R.; Zoing, M.C. Amyotrophic lateral sclerosis. Lancet 2011, 377, 942-955. [CrossRef]

2. Zhang, W.; Zhang, L.; Liang, B.; Schroeder, D.; Zhang, Z.-W.; Cox, G.A.; Li, Y.; Lin, D.-T. Hyperactive somatostatin interneurons contribute to excitotoxicity in neurodegenerative disorders. Nat. Neurosci. 2016, 19, 557-559. [CrossRef]

3. Hardiman, O.; Al-Chalabi, A.; Chio, A.; Corr, E.M.; Logroscino, G.; Robberecht, W.; Shaw, P.J.; Simmons, Z.; van den Berg, L.H. Amyotrophic lateral sclerosis. Nat. Rev. Dis. Primers 2017, 3, 17071. [CrossRef]

4. Chia, R.; Chiò, A.; Traynor, B.J. Novel genes associated with amyotrophic lateral sclerosis: Diagnostic and clinical implications. Lancet Neurol. 2018, 17, 94-102. [CrossRef]

5. Brown, R.H.; Al-Chalabi, A. Amyotrophic Lateral Sclerosis. N. Engl. J. Med. 2017, 377, 162-172. [CrossRef]

6. Chen, S.; Sayana, P.; Zhang, X.; Le, W. Genetics of amyotrophic lateral sclerosis: An update. Mol. Neurodegener. $2013,8,28$. [CrossRef]

7. Mejzini, R.; Flynn, L.L.; Pitout, I.L.; Fletcher, S.; Wilton, S.D.; Akkari, P.A. ALS Genetics, Mechanisms, and Therapeutics: Where Are We Now? Front. Neurosci. 2019, 13, 1310. [CrossRef]

8. Taylor, J.P.; Brown, R.H., Jr.; Cleveland, D.W. Decoding ALS: From genes to mechanism. Nature 2016, 539, 197-206. [CrossRef]

9. Mehta, P.R.; Jones, A.R.; Opie-Martin, S.; Shatunov, A.; Iacoangeli, A.; Al Khleifat, A.; Smith, B.N.; Topp, S.; Morrison, K.E.; Shaw, P.J.; et al. Younger age of onset in familial amyotrophic lateral sclerosis is a result of pathogenic gene variants, rather than ascertainment bias. J. Neurol. Neurosurg. Psychiatry 2018, 90, 268-271. [CrossRef]

10. Renton, A.E.; Chio, A.; Traynor, B.J. State of play in amyotrophic lateral sclerosis genetics. Nat. Neurosci. 2013, 17, 17-23. [CrossRef]

11. Ling, S.C.; Polymenidou, M.; Cleveland, D.W. Converging mechanisms in ALS and FTD: Disrupted RNA and protein homeostasis. Neuron 2013, 79, 416-438. [CrossRef]

12. Neumann, M.; Sampathu Deepak, M.; Kwong Linda, K.; Truax Adam, C.; Micsenyi Matthew, C.; Chou Thomas, T.; Bruce, J.; Schuck, T.; Grossman, M.; Clark Christopher, M.; et al. Ubiquitinated TDP-43 in Frontotemporal Lobar Degeneration and Amyotrophic Lateral Sclerosis. Science 2006, 314, 130-133. [CrossRef]

13. Mori, K.; Weng, S.-M.; Arzberger, T.; May, S.; Rentzsch, K.; Kremmer, E.; Schmid, B.; Kretzschmar, H.A.; Cruts, M.; Van Broeckhoven, C.; et al. The C9orf72 GGGGCC Repeat Is Translated into Aggregating Dipeptide-Repeat Proteins in FTLD/ALS. Science 2013, 339, 1335-1338. [CrossRef]

14. Deng, H.-X.; Zhai, H.; Bigio, E.H.; Yan, J.; Fecto, F.; Ajroud, K.; Mishra, M.; Ajroud-Driss, S.; Heller, S.; Sufit, R.; et al. FUSimmunoreactive inclusions are a common feature in sporadic and non-SOD1 familial amyotrophic lateral sclerosis. Ann. Neurol. 2010, 67, 739-748. [CrossRef]

15. Ikenaka, K.; Ishigaki, S.; Iguchi, Y.; Kawai, K.; Fujioka, Y.; Yokoi, S.; Abdelhamid, R.F.; Nagano, S.; Mochizuki, H.; Katsuno, M.; et al. Characteristic Features of FUS Inclusions in Spinal Motor Neurons of Sporadic Amyotrophic Lateral Sclerosis. J. Neuropathol. Exp. Neurol. 2020, 79, 370-377. [CrossRef]

16. De Boer, E.M.J.; Orie, V.K.; Williams, T.; Baker, M.R.; De Oliveira, H.M.; Polvikoski, T.; Silsby, M.; Menon, P.; van den Bos, M.; Halliday, G.M.; et al. TDP-43 proteinopathies: A new wave of neurodegenerative diseases. J. Neurol. Neurosurg. Psychiatry 2020, 92, 86-95. [CrossRef]

17. Benson, B.C.; Shaw, P.J.; Azzouz, M.; Highley, J.R.; Hautbergue, G.M. Proteinopathies as Hallmarks of Impaired Gene Expression, Proteostasis and Mitochondrial Function in Amyotrophic Lateral Sclerosis. Front. Neurosci. 2021, 15, 783624. [CrossRef]

18. Polymenidou, M.; Lagier-Tourenne, C.; Hutt, K.R.; Bennett, C.F.; Cleveland, D.W.; Yeo, G.W. Misregulated RNA processing in amyotrophic lateral sclerosis. Brain Res. 2012, 1462, 3-15. [CrossRef]

19. Kawamata, H.; Manfredi, G. Mitochondrial dysfunction and intracellular calcium dysregulation in ALS. Mech. Ageing Dev. 2010, 131, 517-526. [CrossRef]

20. Barber, S.C.; Shaw, P.J. Oxidative stress in ALS: Key role in motor neuron injury and therapeutic target. Free Radic. Biol. Med. 2010, 48, 629-641. [CrossRef]

21. Xiao, S.; McLean, J.; Robertson, J. Neuronal intermediate filaments and ALS: A new look at an old question. Biochim. Biophys. Acta BBA-Mol. Basis Dis. 2006, 1762, 1001-1012. [CrossRef] [PubMed]

22. Marinković, P.; Reuter, M.S.; Brill, M.S.; Godinho, L.; Kerschensteiner, M.; Misgeld, T. Axonal transport deficits and degeneration can evolve independently in mouse models of amyotrophic lateral sclerosis. Proc. Natl. Acad. Sci. USA 2012, 109, $4296-4301$. [CrossRef] [PubMed]

23. Leal, S.S.; Cardoso, I.; Valentine, J.S.; Gomes, C.M. Calcium Ions Promote Superoxide Dismutase 1 (SOD1) Aggregation into Non-fibrillar Amyloid: A Link to Toxic Effects of Calcium Overload in Amyotrophic Lateral Sclerosis (ALS)? J. Biol. Chem. 2013, 288, 25219-25228. [CrossRef]

24. Lautenschlaeger, J.; Prell, T.; Grosskreutz, J. Endoplasmic reticulum stress and the ER mitochondria calcium cycle in amyotrophic lateral sclerosis. Amyotroph. Lateral Scler. 2012, 13, 166-177. [CrossRef] [PubMed]

25. Grosskreutz, J.; Bosch, L.V.D.; Keller, B.U. Calcium dysregulation in amyotrophic lateral sclerosis. Cell Calcium 2010, 47, 165-174. [CrossRef]

26. Dupuis, L.; Pradat, P.-F.; Ludolph, A.C.; Loeffler, J.-P. Energy metabolism in amyotrophic lateral sclerosis. Lancet Neurol. 2011, 10, 75-82. [CrossRef] 
27. Schulthess, I.; Gorges, M.; Müller, H.-P.; Lulé, D.; Del Tredici, K.; Ludolph, A.C.; Kassubek, J. Functional connectivity changes resemble patterns of pTDP-43 pathology in amyotrophic lateral sclerosis. Sci. Rep. 2016, 6, 38391. [CrossRef] [PubMed]

28. Gunes, Z.I.; Kan, V.W.Y.; Ye, X.; Liebscher, S. Exciting Complexity: The Role of Motor Circuit Elements in ALS Pathophysiology. Front. Neurosci. 2020, 14, 573. [CrossRef]

29. Gunes, T.; Sirin, N.G.; Sahin, S.; Kose, E.; Isak, B. Use of CMAP, MScan fit-MUNE, and MUNIX in understanding neurodegeneration pattern of ALS and detection of early motor neuron loss in daily practice. Neurosci. Lett. 2020, 741, 135488. [CrossRef]

30. Dadon-Nachum, M.; Melamed, E.; Offen, D. The "Dying-Back" Phenomenon of Motor Neurons in ALS. J. Mol. Neurosci. 2011, 43, 470-477. [CrossRef]

31. Eisen, A.; Weber, M. The motor cortex and amyotrophic lateral sclerosis. Muscle Nerve 2001, 24, 564-573. [CrossRef] [PubMed]

32. Braak, H.; Brettschneider, J.; Ludolph, A.C.; Lee, V.M.; Trojanowski, J.Q.; Del Tredici, K. Amyotrophic lateral sclerosis-A model of corticofugal axonal spread. Nat. Rev. Neurol. 2013, 9, 708-714. [CrossRef]

33. Baker, M.R. ALS—dying forward, backward or outward? Nat. Rev. Neurol. 2014, 10, 660. [CrossRef]

34. Grieve, S.M.; Menon, P.; Korgaonkar, M.S.; Gomes, L.; Foster, S.; Kiernan, M.C.; Vucic, S. Potential structural and functional biomarkers of upper motor neuron dysfunction in ALS. Amyotroph. Lateral Scler. Front. Degener. 2015, 17, 85-92. [CrossRef] [PubMed]

35. Geevasinga, N.; Van den Bos, M.; Menon, P.; Vucic, S. Utility of Transcranial Magnetic Simulation in Studying Upper Motor Neuron Dysfunction in Amyotrophic Lateral Sclerosis. Brain Sci. 2021, 11, 906. [CrossRef] [PubMed]

36. Vucic, S.; Nicholson, G.A.; Kiernan, M.C. Cortical hyperexcitability may precede the onset of familial amyotrophic lateral sclerosis. Brain 2008, 131, 1540-1550. [CrossRef] [PubMed]

37. Kujirai, T.; Caramia, M.D.; Rothwell, J.C.; Day, B.L.; Thompson, P.D.; Ferbert, A.; Wroe, S.; Asselman, P.; Marsden, C.D Corticocortical inhibition in human motor cortex. J. Physiol. 1993, 471, 501-519. [CrossRef]

38. Vucic, S.; Kiernan, M.C. Axonal excitability properties in amyotrophic lateral sclerosis. Clin. Neurophysiol. 2006, 117, 1458-1466. [CrossRef]

39. Menke, R.A.L.; Agosta, F.; Grosskreutz, J.; Filippi, M.; Turner, M.R. Neuroimaging Endpoints in Amyotrophic Lateral Sclerosis Neurotherapeutics 2016, 14, 11-23. [CrossRef] [PubMed]

40. Vucic, S.; Pavey, N.; Haidar, M.; Turner, B.J.; Kiernan, M.C. Cortical hyperexcitability: Diagnostic and pathogenic biomarker of ALS. Neurosci. Lett. 2021, 759, 136039. [CrossRef]

41. Vucic, S.; van den Bos, M.; Menon, P.; Howells, J.; Dharmadasa, T.; Kiernan, M.C. Utility of threshold tracking transcranial magnetic stimulation in ALS. Clin. Neurophysiol. Pract. 2018, 3, 164-172. [CrossRef] [PubMed]

42. McMackin, R.; Dukic, S.; Costello, E.; Pinto-Grau, M.; McManus, L.; Broderick, M.; Chipika, R.; Iyer, P.M.; Heverin, M.; Bede, P.; et al. Cognitive network hyperactivation and motor cortex decline correlate with ALS prognosis. Neurobiol. Aging 2021, 104, 57-70. [CrossRef] [PubMed]

43. Hallett, M. Transcranial Magnetic Stimulation: A Primer. Neuron 2007, 55, 187-199. [CrossRef]

44. Triggs, W.J.; Menkes, D.; Onorato, J.; Yan, R.S.H.; Young, M.S.; Newell, K.; Sander, H.W.; Soto, O.; Chiappa, K.H.; Cros, D. Transcranial magnetic stimulation identifies upper motor neuron involvement in motor neuron disease. Neurology 1999, 53, 605 . [CrossRef]

45. Agarwal, S.; Highton-Williamson, E.; Caga, J.; Howells, J.; Dharmadasa, T.; Matamala, J.M.; Ma, Y.; Shibuya, K.; Hodges, J.R.; Ahmed, R.M.; et al. Motor cortical excitability predicts cognitive phenotypes in amyotrophic lateral sclerosis. Sci. Rep. 2021, 11, 2172. [CrossRef] [PubMed]

46. Zanette, G.; Tamburin, S.; Manganotti, P.; Refatti, N.; Forgione, A.; Rizzuto, N. Changes in motor cortex inhibition over time in patients with amyotrophic lateral sclerosis. J. Neurol. 2002, 249, 1723-1728. [CrossRef] [PubMed]

47. Mills, K.R. Motor neuron disease. Brain 1995, 118, 971-982. [CrossRef]

48. Rösler, K.; Truffert, A.; Hess, C.; Magistris, M. Quantification of upper motor neuron loss in amyotrophic lateral sclerosis. Clin. Neurophysiol. 2000, 111, 2208-2218. [CrossRef]

49. Prout, A.J.; Eisen, A.A. The cortical silent period and amyotrophic lateral sclerosis. Muscle Nerve 1994, 17, 217-223. [CrossRef]

50. Yokota, T.; Yoshino, A.; Inaba, A.; Saito, Y. Double cortical stimulation in amyotrophic lateral sclerosis. J. Neurol. Neurosurg. Psychiatry 1996, 61, 596-600. [CrossRef] [PubMed]

51. Ziemann, U.; Winter, M.; Reimers, C.D.; Reimers, K.; Tergau, F.; Paulus, W. Impaired motor cortex inhibition in patients with amyotrophic lateral sclerosis: Evidence from paired transcranial magnetic stimulation. Neurology 1997, 49, 1292-1298. [CrossRef] [PubMed]

52. Eisen, A.; Weber, M. Neurophysiological evaluation of cortical function in the early diagnosis of ALS. Amyotroph. Lateral Scler. 2000, 1, S47-S51. [CrossRef]

53. Turner, M.R.; Osei-Lah, A.D.; Hammers, A.; Al-Chalabi, A.; Shaw, C.; Andersen, P.M.; Brooks, D.; Leigh, P.N.; Mills, K.R. Abnormal cortical excitability in sporadic but not homozygous D90A SOD1 ALS. J. Neurol. Neurosurg. Psychiatry 2005, 76, 1279-1285. [CrossRef] [PubMed]

54. Vucic, S.; Cheah, B.C.; Yiannikas, C.; Kiernan, M.C. Cortical excitability distinguishes ALS from mimic disorders. Clin. Neurophysiol. 2011, 122, 1860-1866. [CrossRef]

55. Menon, P.; Kiernan, M.C.; Vucic, S. Cortical hyperexcitability precedes lower motor neuron dysfunction in ALS. Clin. Neurophysiol. 2015, 126, 803-809. [CrossRef] 
56. Tankisi, H.; Nielsen, C.S.-Z.; Howells, J.; Cengiz, B.; Samusyte, G.; Koltzenburg, M.; Blicher, J.U.; Møller, A.T.; Pugdahl, K.; Fuglsang-Frederiksen, A.; et al. Early diagnosis of amyotrophic lateral sclerosis by threshold tracking and conventional transcranial magnetic stimulation. Eur. J. Neurol. 2021, 28, 3030-3039. [CrossRef] [PubMed]

57. Werhahn, K.J.; Kunesch, E.; Noachtar, S.; Benecke, R.; Classen, J. Differential effects on motorcortical inhibition induced by blockade of GABA uptake in humans. J. Physiol. 1999, 517, 591-597. [CrossRef] [PubMed]

58. Ziemann, U.; Tergau, F.; Wassermann, E.M.; Wischer, S.; Hildebrandt, J.; Paulus, W. Demonstration of facilitatory I wave interaction in the human motor cortex by paired transcranial magnetic stimulation. J. Physiol. 1998, 511, 181-190. [CrossRef]

59. Ziemann, U.; Reis, J.; Schwenkreis, P.; Rosanova, M.; Strafella, A.; Badawy, R.; Müller-Dahlhaus, F. TMS and drugs revisited 2014. Clin. Neurophysiol. 2015, 126, 1847-1868. [CrossRef]

60. Menon, P.; Geevasinga, N.; Bos, M.V.D.; Yiannikas, C.; Kiernan, M.C.; Vucic, S. Cortical hyperexcitability and disease spread in amyotrophic lateral sclerosis. Eur. J. Neurol. 2017, 24, 816-824. [CrossRef]

61. Van den Bos, M.A.J.; Higashihara, M.; Geevasinga, N.; Menon, P.; Kiernan, M.C.; Vucic, S. Imbalance of cortical facilitatory and inhibitory circuits underlies hyperexcitability in ALS. Neurology 2018, 91, e1669-e1676. [CrossRef] [PubMed]

62. Pfurtscheller, G.; Lopes da Silva, F.H. Event-related EEG/MEG synchronization and desynchronization: Basic principles. Clin. Neurophysiol. 1999, 110, 1842-1857. [CrossRef]

63. Kasahara, T.; Terasaki, K.; Ogawa, Y.; Ushiba, J.; Aramaki, H.; Masakado, Y. The correlation between motor impairments and event-related desynchronization during motor imagery in ALS patients. BMC Neurosci. 2012, 13, 66. [CrossRef] [PubMed]

64. Bizovičar, N.; Dreo, J.; Koritnik, B.; Zidar, J. Decreased movement-related beta desynchronization and impaired post-movement beta rebound in amyotrophic lateral sclerosis. Clin. Neurophysiol. 2014, 125, 1689-1699. [CrossRef]

65. Riva, N.; Falini, A.; Inuggi, A.; Gonzalez-Rosa, J.; Amadio, S.; Cerri, F.; Fazio, R.; Del Carro, U.; Comola, M.; Comi, G.; et al Cortical activation to voluntary movement in amyotrophic lateral sclerosis is related to corticospinal damage: Electrophysiological evidence. Clin. Neurophysiol. 2012, 123, 1586-1592. [CrossRef]

66. Proudfoot, M.; Rohenkohl, G.; Quinn, A.; Colclough, G.L.; Wuu, J.; Talbot, K.; Woolrich, M.W.; Benatar, M.; Nobre, A.C.; Turner, M.R. Altered cortical beta-band oscillations reflect motor system degeneration in amyotrophic lateral sclerosis. Hum. Brain Mapp. 2016, 38, 237-254. [CrossRef] [PubMed]

67. Logothetis, N.K. What we can do and what we cannot do with fMRI. Nature 2008, 453, 869-878. [CrossRef]

68. Hermes, D.; Nguyen, M.; Winawer, J. Neuronal synchrony and the relation between the blood-oxygen-level dependent response and the local field potential. PLoS Biol. 2017, 15, e2001461. [CrossRef]

69. Konrad, C.; Jansen, A.; Henningsen, H.; Sommer, J.; Turski, P.A.; Brooks, B.R.; Knecht, S. Subcortical reorganization in amyotrophic lateral sclerosis. Exp. Brain Res. 2006, 172, 361-369. [CrossRef]

70. Schoenfeld, M.A.; Tempelmann, C.; Gaul, C.; Kühnel, G.R.; Düzel, E.; Hopf, J.-M.; Feistner, H.; Zierz, S.; Heinze, H.-J.; Vielhaber, S. Functional motor compensation in amyotrophic lateral sclerosis. J. Neurol. 2005, 252, 944-952. [CrossRef]

71. Douaud, G.; Filippini, N.; Knight, S.; Talbot, K.; Turner, M. Integration of structural and functional magnetic resonance imaging in amyotrophic lateral sclerosis. Brain 2011, 134, 3470-3479. [CrossRef] [PubMed]

72. Agosta, F.; Spinelli, E.G.; Marjanovic, I.V.; Stevic, Z.; Pagani, E.; Valsasina, P.; Salak-Djokic, B.; Jankovic, M.; Lavrnic, D.; Kostic, V.S.; et al. Unraveling ALS due to SOD1 mutation through the combination of brain and cervical cord MRI. Neurology 2018, 90, e707-e716. [CrossRef] [PubMed]

73. Li, W.; Zhang, J.; Zhou, C.; Hou, W.; Hu, J.; Feng, H.; Zheng, X. Abnormal Functional Connectivity Density in Amyotrophic Lateral Sclerosis. Front. Aging Neurosci. 2018, 10, 215. [CrossRef] [PubMed]

74. Commisso, B.; Ding, L.; Varadi, K.; Gorges, M.; Bayer, D.; Boeckers, T.M.; Ludolph, A.C.; Kassubek, J.; Müller, O.J.; Roselli, F. Stage-dependent remodeling of projections to motor cortex in ALS mouse model revealed by a new variant retrograde-AAV9. eLife 2018, 7, e36892. [CrossRef] [PubMed]

75. Proudfoot, M.; Colclough, G.L.; Quinn, A.; Wuu, J.; Talbot, K.; Benatar, M.; Nobre, A.C.; Woolrich, M.W.; Turner, M.R. Increased cerebral functional connectivity in ALS. Neurology 2018, 90, e1418-e1424. [CrossRef] [PubMed]

76. Foerster, B.R.; Callaghan, B.C.; Petrou, M.; Den, R.A.E.; Chenevert, T.L.; Feldman, E.L. Decreased motor cortex $\gamma$-aminobutyric acid in amyotrophic lateral sclerosis. Neurology 2012, 78, 1596-1600. [CrossRef]

77. Foerster, B.R.; Pomper, M.G.; Callaghan, B.C.; Petrou, M.; Edden, R.; Mohamed, M.; Welsh, R.C.; Carlos, R.C.; Barker, P.B.; Feldman, E. An Imbalance Between Excitatory and Inhibitory Neurotransmitters in Amyotrophic Lateral Sclerosis Revealed by Use of 3-T Proton Magnetic Resonance Spectroscopy. JAMA Neurol. 2013, 70, 1009-1016. [CrossRef]

78. Petri, S.; Krampfl, K.; Hashemi, F.; Grothe, C.; Hori, A.; Dengler, R.; Bufler, J. Distribution of GABAAReceptor mRNA in the Motor Cortex of ALS Patients. J. Neuropathol. Exp. Neurol. 2003, 62, 1041-1051. [CrossRef]

79. Aronica, E.; Baas, F.; Iyer, A.; Asbroek, A.L.T.; Morello, G.; Cavallaro, S. Molecular classification of amyotrophic lateral sclerosis by unsupervised clustering of gene expression in motor cortex. Neurobiol. Dis. 2014, 74, 359-376. [CrossRef]

80. Fujimori, K.; Ishikawa, M.; Otomo, A.; Atsuta, N.; Nakamura, R.; Akiyama, T.; Hadano, S.; Aoki, M.; Saya, H.; Sobue, G.; et al. Modeling sporadic ALS in iPSC-derived motor neurons identifies a potential therapeutic agent. Nat. Med. 2018, 24, 1579-1589. [CrossRef]

81. Wainger, B.J.; Kiskinis, E.; Mellin, C.; Wiskow, O.; Han, S.S.W.; Sandoe, J.; Perez, N.P.; Williams, L.A.; Lee, S.; Boulting, G.; et al. Intrinsic Membrane Hyperexcitability of Amyotrophic Lateral Sclerosis Patient-Derived Motor Neurons. Cell Rep. 2014, 7, 1-11. [CrossRef] [PubMed] 
82. Devlin, A.-C.; Burr, K.; Borooah, S.; Foster, J.; Cleary, E.M.; Geti, I.; Vallier, L.; Shaw, C.; Chandran, S.; Miles, G. Human iPSCderived motoneurons harbouring TARDBP or C9ORF72 ALS mutations are dysfunctional despite maintaining viability. Nat. Commun. 2015, 6, 5999. [CrossRef]

83. Sareen, D.; O’Rourke, J.G.; Meera, P.; Muhammad, A.K.M.G.; Grant, S.; Simpkinson, M.; Bell, S.; Carmona, S.; Ornelas, L.; Sahabian, A.; et al. Targeting RNA Foci in iPSC-Derived Motor Neurons from ALS Patients with a C9ORF72 Repeat Expansion. Sci. Transl. Med. 2013, 5, 208ra149. [CrossRef] [PubMed]

84. Kim, B.W.; Ryu, J.; Jeong, Y.E.; Kim, J.; Martin, L.J. Human Motor Neurons With SOD1-G93A Mutation Generated From CRISPR/Cas9 Gene-Edited iPSCs Develop Pathological Features of Amyotrophic Lateral Sclerosis. Front. Cell. Neurosci. 2020, 14, 604171. [CrossRef] [PubMed]

85. Naujock, M.; Stanslowsky, N.; Bufler, S.; Naumann, M.; Reinhardt, P.; Sterneckert, J.; Kefalakes, E.; Kassebaum, C.; Bursch, F.; Lojewski, X.; et al. 4-Aminopyridine Induced Activity Rescues Hypoexcitable Motor Neurons from Amyotrophic Lateral Sclerosis Patient-Derived Induced Pluripotent Stem Cells. Stem Cells 2016, 34, 1563-1575. [CrossRef] [PubMed]

86. Nijssen, J.; Comley, L.H.; Hedlund, E. Motor neuron vulnerability and resistance in amyotrophic lateral sclerosis. Acta Neuropathol. 2017, 133, 863-885. [CrossRef]

87. Perkins, E.M.; Burr, K.; Banerjee, P.; Mehta, A.R.; Dando, O.; Selvaraj, B.T.; Suminaite, D.; Nanda, J.; Henstridge, C.M.; Gillingwater, T.H.; et al. Altered network properties in C9ORF72 repeat expansion cortical neurons are due to synaptic dysfunction. Mol. Neurodegener. 2021, 16, 13. [CrossRef] [PubMed]

88. Szebényi, K.; Wenger, L.M.D.; Sun, Y.; Dunn, A.W.E.; Limegrover, C.A.; Gibbons, G.M.; Conci, E.; Paulsen, O.; Mierau, S.B.; Balmus, G.; et al. Human ALS/FTD brain organoid slice cultures display distinct early astrocyte and targetable neuronal pathology. Nat. Neurosci. 2021, 24, 1542-1554. [CrossRef] [PubMed]

89. Andersen, J.; Revah, O.; Miura, Y.; Thom, N.; Amin, N.D.; Kelley, K.W.; Singh, M.; Chen, X.; Thete, M.V.; Walczak, E.M.; et al. Generation of Functional Human 3D Cortico-Motor Assembloids. Cell 2020, 183, 1913-1929.e26. [CrossRef]

90. Haidar, M.; Viden, A.; Cuic, B.; Wang, T.; Rosier, M.; Tomas, D.; Mills, S.A.; Govier-Cole, A.; Djouma, E.; Luikinga, S.; et al. Cortical hyperexcitability drives dying forward ALS symptoms and pathology in mice. bioRxiv 2021. [CrossRef]

91. Shepherd, G.M.G. Corticostriatal connectivity and its role in disease. Nat. Rev. Neurosci. 2013, 14, 278-291. [CrossRef] [PubMed]

92. Nigro, M.J.; Hashikawa-Yamasaki, Y.; Rudy, B. Diversity and Connectivity of Layer 5 Somatostatin-Expressing Interneurons in the Mouse Barrel Cortex. J. Neurosci. 2018, 38, 1622-1633. [CrossRef] [PubMed]

93. Swanson, O.K.; Maffei, A. From Hiring to Firing: Activation of Inhibitory Neurons and Their Recruitment in Behavior. Front. Mol. Neurosci. 2019, 12, 168. [CrossRef] [PubMed]

94. Rudy, B.; Fishell, G.; Lee, S.; Hjerling-Leffler, J. Three groups of interneurons account for nearly $100 \%$ of neocortical GABAergic neurons. Dev. Neurobiol. 2011, 71, 45-61. [CrossRef] [PubMed]

95. Tremblay, R.; Lee, S.; Rudy, B. GABAergic interneurons in the neocortex: From cellular properties to circuits. Neuron 2016, 91, 260-292. [CrossRef] [PubMed]

96. Wood, K.; Blackwell, J.M.; Geffen, M.N. Cortical inhibitory interneurons control sensory processing. Curr. Opin. Neurobiol. 2017, 46, 200-207. [CrossRef]

97. Lee, S.; Kruglikov, I.; Huang, Z.J.; Fishell, G.; Rudy, B. A disinhibitory circuit mediates motor integration in the somatosensory cortex. Nat. Neurosci. 2013, 16, 1662-1670. [CrossRef]

98. Yu, J.; Hu, H.; Agmon, A.; Svoboda, K. Recruitment of GABAergic interneurons in the barrel cortex during active tactile behavior. Neuron 2019, 104, 412-427.e414. [CrossRef]

99. Gu, Q. Neuromodulatory transmitter systems in the cortex and their role in cortical plasticity. Neuroscience 2002, 111, 815-835 [CrossRef]

100. Conner, J.M.; Kulczycki, M.; Tuszynski, M.H. Unique Contributions of Distinct Cholinergic Projections to Motor Cortical Plasticity and Learning. Cereb. Cortex 2010, 20, 2739-2748. [CrossRef]

101. Vitrac, C.; Benoit-Marand, M. Monoaminergic Modulation of Motor Cortex Function. Front. Neural Circuits 2017, 11, 72. [CrossRef]

102. Fogarty, M.J.; Mu, E.W.H.; Noakes, P.; Lavidis, N.A.; Bellingham, M.C. Marked changes in dendritic structure and spine density precede significant neuronal death in vulnerable cortical pyramidal neuron populations in the SOD1G93A mouse model of amyotrophic lateral sclerosis. Acta Neuropathol. Commun. 2016, 4, 77. [CrossRef]

103. Fogarty, M.J.; Noakes, P.; Bellingham, M.C. Motor Cortex Layer V Pyramidal Neurons Exhibit Dendritic Regression, Spine Loss, and Increased Synaptic Excitation in the Presymptomatic hSOD1G93A Mouse Model of Amyotrophic Lateral Sclerosis. J. Neurosci. 2015, 35, 643-647. [CrossRef]

104. Fogarty, M.J.; Klenowski, P.M.; Lee, J.D.; Drieberg-Thompson, J.R.; Bartlett, S.E.; Ngo, S.T.; Hilliard, M.A.; Bellingham, M.C.; Noakes, P.G. Cortical synaptic and dendritic spine abnormalities in a presymptomatic TDP-43 model of amyotrophic lateral sclerosis. Sci. Rep. 2016, 6, 37968. [CrossRef] [PubMed]

105. Kim, J.; Hughes, E.G.; Shetty, A.S.; Arlotta, P.; Goff, L.; Bergles, D.E.; Brown, S.P. Changes in the Excitability of Neocortical Neurons in a Mouse Model of Amyotrophic Lateral Sclerosis Are Not Specific to Corticospinal Neurons and Are Modulated by Advancing Disease. J. Neurosci. 2017, 37, 9037-9053. [CrossRef]

106. Buskila, Y.; Kékesi, O.; Bellot-Saez, A.; Seah, W.; Berg, T.; Trpceski, M.; Yerbury, J.; Ooi, L. Dynamic interplay between H-current and M-current controls motoneuron hyperexcitability in amyotrophic lateral sclerosis. Cell Death Dis. 2019, 10, 310. [CrossRef] 
107. Saba, L.; Viscomi, M.T.; Martini, A.; Caioli, S.; Mercuri, N.B.; Guatteo, E.; Zona, C. Modified age-dependent expression of NaV1.6 in an ALS model correlates with motor cortex excitability alterations. Neurobiol. Dis. 2019, 130, 104532. [CrossRef]

108. Dyer, M.S.; Reale, L.A.; Lewis, K.E.; Walker, A.K.; Dickson, T.C.; Woodhouse, A.; Blizzard, C.A. Mislocalisation of TDP-43 to the cytoplasm causes cortical hyperexcitability and reduced excitatory neurotransmission in the motor cortex. J. Neurochem. 2020, 157, 1300-1315. [CrossRef]

109. Schmitt-John, T.; Drepper, C.; Mußmann, A.; Hahn, P.; Kuhlmann, M.; Thiel, C.; Hafner, M.; Lengeling, A.; Heimann, P.; Jones, J.M.; et al. Mutation of Vps54 causes motor neuron disease and defective spermiogenesis in the wobbler mouse. Nat. Genet. 2005, 37, 1213-1215. [CrossRef] [PubMed]

110. Nieto-Gonzalez, J.L.; Moser, J.; Lauritzen, M.; Schmitt-John, T.; Jensen, K. Reduced GABAergic Inhibition Explains Cortical Hyperexcitability in the Wobbler Mouse Model of ALS. Cereb. Cortex 2011, 21, 625-635. [CrossRef] [PubMed]

111. Scekic-Zahirovic, J.; Sanjuan-Ruiz, I.; Kan, V.; Megat, S.; De Rossi, P.; Dieterlé, S.; Cassel, R.; Jamet, M.; Kessler, P.; Wiesner, D.; et al. Cytoplasmic FUS triggers early behavioral alterations linked to cortical neuronal hyperactivity and inhibitory synaptic defects. Nat. Commun. 2021, 12, 3028. [CrossRef] [PubMed]

112. Khademullah, C.S.; Aqrabawi, A.J.; Place, K.M.; Dargaei, Z.; Liang, X.; Pressey, J.C.; Bedard, S.; Yang, J.W.; Garand, D.; Keramidis, I.; et al. Cortical interneuron-mediated inhibition delays the onset of amyotrophic lateral sclerosis. Brain 2020, 143, 800-810. [CrossRef] [PubMed]

113. Özdinler, P.H.; Benn, S.; Yamamoto, T.H.; Güzel, M.; Brown, R.H.; Macklis, J.D. Corticospinal Motor Neurons and Related Subcerebral Projection Neurons Undergo Early and Specific Neurodegeneration in hSOD1G93A Transgenic ALS Mice. J. Neurosci. 2011, 31, 4166-4177. [CrossRef] [PubMed]

114. Clark, R.M.; Blizzard, C.A.; Young, K.M.; King, A.E.; Dickson, T.C. Calretinin and Neuropeptide Y interneurons are differentially altered in the motor cortex of the SOD1 ${ }^{\text {G93A }}$ mouse model of ALS. Sci. Rep. 2017, 7, 44461. [CrossRef] [PubMed]

115. Brunet, A.; Stuart-Lopez, G.; Burg, T.; Scekic-Zahirovic, J.; Rouaux, C. Cortical Circuit Dysfunction as a Potential Driver of Amyotrophic Lateral Sclerosis. Front. Neurosci. 2020, 14, 363. [CrossRef] [PubMed]

116. Takahashi, H.; Snow, B.J.; Bhatt, M.H.; Peppard, R.; Eisen, A.; Calne, D.B. Evidence for a dopaminergic deficit in sporadic amyotrophic lateral sclerosis on positron emission scanning. Lancet 1993, 342, 1016-1018. [CrossRef]

117. Borasio, G.D.; Linke, R.; Schwarz, J.; Schlamp, V.; Abel, A.; Mozley, P.D.; Tatsch, K. Dopaminergic deficit in amyotrophic lateral sclerosis assessed with [I-123] IPT single photon emission computed tomography. J. Neurol. Neurosurg. Psychiatry 1998, 65, 263-265. [CrossRef]

118. Kostic, V.; Gurney, M.E.; Deng, H.-X.; Siddique, T.; Epstein, C.J.; Przedborski, S. Midbrain dopaminergic neuronal degeneration in a transgenic mouse model of familial amyotrophic lateral sclerosis. Ann. Neurol. 1997, 41, 497-504. [CrossRef]

119. Dentel, C.; Palamiuc, L.; Henriques, A.; Lannes, B.; Spreux-Varoquaux, O.; Gutknecht, L.; René, F.; Echaniz-Laguna, A.; De Aguilar, J.-L.G.; Lesch, K.P.; et al. Degeneration of serotonergic neurons in amyotrophic lateral sclerosis: A link to spasticity. Brain 2013, 136, 483-493. [CrossRef]

120. Verkhratsky, A.; Nedergaard, M. Physiology of Astroglia. Physiol. Rev. 2018, 98, 239-389. [CrossRef]

121. Durkee, C.A.; Araque, A. Diversity and Specificity of Astrocyte-neuron Communication. Neuroscience 2018, 396, 73-78. [CrossRef] [PubMed]

122. Rothstein, J.D.; Van Kammen, M.; Levey, A.I.; Martin, L.J.; Kuncl, R.W. Selective loss of glial glutamate transporter GLT-1 in amyotrophic lateral sclerosis. Ann. Neurol. 1995, 38, 73-84. [CrossRef] [PubMed]

123. Kelley, K.W.; Ben Haim, L.; Schirmer, L.; Tyzack, G.; Tolman, M.; Miller, J.G.; Tsai, H.-H.; Chang, S.M.; Molofsky, A.V.; Yang, Y.; et al. Kir4.1-Dependent Astrocyte-Fast Motor Neuron Interactions Are Required for Peak Strength. Neuron 2018, 98, 306-319.e7. [CrossRef] [PubMed]

124. Bruijn, L.I.; Becher, M.W.; Lee, M.K.; Anderson, K.L.; Jenkins, N.A.; Copeland, N.G.; Sisodia, S.S.; Rothstein, J.D.; Borchelt, D.R.; Price, D.L.; et al. ALS-Linked SOD1 Mutant G85R Mediates Damage to Astrocytes and Promotes Rapidly Progressive Disease with SOD1-Containing Inclusions. Neuron 1997, 18, 327-338. [CrossRef]

125. Howland, D.S.; Liu, J.; She, Y.; Goad, B.; Maragakis, N.J.; Kim, B.; Erickson, J.; Kulik, J.; DeVito, L.; Psaltis, G.; et al. Focal loss of the glutamate transporter EAAT2 in a transgenic rat model of SOD1 mutant-mediated amyotrophic lateral sclerosis (ALS). Proc. Natl. Acad. Sci. USA 2002, 99, 1604-1609. [CrossRef] [PubMed]

126. Wilson, J.M.B.; Khabazian, I.; Pow, D.V.; Craig, U.K.; Shaw, C.A. Decrease in Glial Glutamate Transporter Variants and Excitatory Amino Acid Receptor Down-Regulation in a Murine Model of ALS-PDC. NeuroMol. Med. 2003, 3, 105-118. [CrossRef]

127. Bendotti, C.; Tortarolo, M.; Suchak, S.K.; Calvaresi, N.; Carvelli, L.; Bastone, A.; Rizzi, M.; Rattray, M.; Mennini, T. Transgenic SOD1 G93A mice develop reduced GLT-1 in spinal cord without alterations in cerebrospinal fluid glutamate levels. J. Neurochem. 2008, 79, 737-746. [CrossRef]

128. Sasaki, S.; Komori, T.; Iwata, M. Excitatory amino acid transporter 1 and 2 immunoreactivity in the spinal cord in amyotrophic lateral sclerosis. Acta Neuropathol. 2000, 100, 138-144. [CrossRef] [PubMed]

129. Jacob, C.; Koutsilieri, E.; Bartl, J.; Neuen-Jacob, E.; Arzberger, T.; Zander, N.; Ravid, R.; Roggendorf, W.; Riederer, P.; Grünblatt, E. Alterations in Expression of Glutamatergic Transporters and Receptors in Sporadic Alzheimer's Disease. J. Alzheimers Dis. 2007, 11, 97-116. [CrossRef]

130. Matos, M.; Augusto, E.; Oliveira, C.; Agostinho, P. Amyloid-beta peptide decreases glutamate uptake in cultured astrocytes: Involvement of oxidative stress and mitogen-activated protein kinase cascades. Neuroscience 2008, 156, 898-910. [CrossRef] 
131. Pitt, D.; Werner, P.; Raine, C.S. Glutamate excitotoxicity in a model of multiple sclerosis. Nat. Med. 2000, 6, 67-70. [CrossRef] [PubMed]

132. Bataveljić, D.; Nikolić, L.; Milosević, M.; Todorović, N.; Andjus, P.R. Changes in the astrocytic aquaporin-4 and inwardly rectifying potassium channel expression in the brain of the amyotrophic lateral sclerosis SOD1G93Arat model. Glia 2012, 60, $1991-2003$. [CrossRef]

133. Kaiser, M.; Maletzki, I.; Hülsmann, S.; Holtmann, B.; Schulz-Schaeffer, W.; Kirchhoff, F.; Bähr, M.; Neusch, C. Progressive loss of a glial potassium channel (KCNJ10) in the spinal cord of the SOD1 (G93A) transgenic mouse model of amyotrophic lateral sclerosis. J. Neurochem. 2006, 99, 900-912. [CrossRef]

134. Bay, V.; Butt, A.M. Relationship between glial potassium regulation and axon excitability: A role for glial Kir4.1 channels. Glia 2012, 60, 651-660. [CrossRef]

135. Magistretti, P.J.; Allaman, I. Lactate in the brain: From metabolic end-product to signalling molecule. Nat. Rev. Neurosci. 2018, 19, 235-249. [CrossRef]

136. Pellerin, L.; Magistretti, P.J. Glutamate uptake into astrocytes stimulates aerobic glycolysis: A mechanism coupling neuronal activity to glucose utilization. Proc. Natl. Acad. Sci. USA 1994, 91, 10625-10629. [CrossRef] [PubMed]

137. Lei, H.; Dirren, E.; Poitry-Yamate, C.; Schneider, B.L.; Gruetter, R.; Aebischer, P. Evolution of the neurochemical profiles in the G93A-SOD1 mouse model of amyotrophic lateral sclerosis. J. Cereb. Blood Flow Metab. 2018, 39, 1283-1298. [CrossRef]

138. Ros, J.; Pecinska, N.; Alessandri, B.; Landolt, H.; Fillenz, M. Lactate reduces glutamate-induced neurotoxicity in rat cortex. J. Neurosci. Res. 2001, 66, 790-794. [CrossRef]

139. Maji Hounoum, B.; Mavel, S.; Coque, E.; Patin, F.; Vourc'H, P.; Marouillat, S.; Nadal-Desbarats, L.; Emond, P.; Corcia, P.; Andres, C.; et al. Wildtype motoneurons, ALS-Linked SOD1 mutation and glutamate profoundly modify astrocyte metabolism and lactate shuttling. Glia 2017, 65, 592-605. [CrossRef]

140. Nagai, M.; Re, D.; Nagata, T.; Chalazonitis, A.; Jessell, T.M.; Wichterle, H.; Przedborski, S. Astrocytes expressing ALS-linked mutated SOD1 release factors selectively toxic to motor neurons. Nat. Neurosci. 2007, 10, 615-622. [CrossRef]

141. Re, D.; Le Verche, V.; Yu, C.; Amoroso, M.W.; Politi, K.A.; Phani, S.; Ikiz, B.; Hoffmann, L.; Koolen, M.; Nagata, T.; et al. Necroptosis Drives Motor Neuron Death in Models of Both Sporadic and Familial ALS. Neuron 2014, 81, 1001-1008. [CrossRef] [PubMed]

142. Rojas, F.; Cortes, N.; Abarzua, S.; Dyrda, A.; Van Zundert, B.A. Astrocytes expressing mutant SOD1 and TDP43 trigger motoneuron death that is mediated via sodium channels and nitroxidative stress. Front. Cell. Neurosci. 2014, 8, 24. [CrossRef]

143. Zhao, C.; Devlin, A.; Chouhan, A.K.; Selvaraj, B.T.; Stavrou, M.; Burr, K.; Brivio, V.; He, X.; Mehta, A.R.; Story, D.; et al. Mutant C9orf72 human iPSC-derived astrocytes cause non-cell autonomous motor neuron pathophysiology. Glia 2019, 68, 1046-1064. [CrossRef] [PubMed]

144. Guttenplan, K.A.; Weigel, M.K.; Prakash, P.; Wijewardhane, P.R.; Hasel, P.; Rufen-Blanchette, U.; Münch, A.E.; Blum, J.A.; Fine, J.; Neal, M.C.; et al. Neurotoxic reactive astrocytes induce cell death via saturated lipids. Nature 2021, 599, 102-107. [CrossRef] [PubMed]

145. Fritz, E.; Izaurieta, P.; Weiss, A.; Mir, F.R.; Rojas, P.; Gonzalez, D.; Rojas, F.; Brown, R.H.; Madrid, R.; Van Zundert, B. Mutant SOD1-expressing astrocytes release toxic factors that trigger motoneuron death by inducing hyperexcitability. J. Neurophysiol. 2013, 109, 2803-2814. [CrossRef] [PubMed]

146. Díaz-Amarilla, P.; Olivera-Bravo, S.; Trias, E.; Cragnolini, A.; Martínez-Palma, L.; Cassina, P.; Beckman, J.; Barbeito, L. Phenotypically aberrant astrocytes that promote motoneuron damage in a model of inherited amyotrophic lateral sclerosis. Proc. Natl. Acad. Sci. USA 2011, 108, 18126-18131. [CrossRef]

147. Liddelow, S.A.; Guttenplan, K.A.; Clarke, L.E.; Bennett, F.C.; Bohlen, C.J.; Schirmer, L.; Bennett, M.L.; Münch, A.E.; Chung, W.-S.; Peterson, T.C.; et al. Neurotoxic reactive astrocytes are induced by activated microglia. Nature 2017, 541, 481-487. [CrossRef] [PubMed]

148. Guttenplan, K.A.; Weigel, M.K.; Adler, D.I.; Couthouis, J.; Liddelow, S.A.; Gitler, A.D.; Barres, B.A. Knockout of reactive astrocyte activating factors slows disease progression in an ALS mouse model. Nat. Commun. 2020, 11, 3753. [CrossRef]

149. Smolič, T.; Tavčar, P.; Horvat, A.; Černe, U.; Vasle, A.H.; Tratnjek, L.; Kreft, M.E.; Scholz, N.; Matis, M.; Petan, T.; et al. Astrocytes in stress accumulate lipid droplets. Glia 2021, 69, 1540-1562. [CrossRef]

150. Taha, D.M.; Clarke, B.E.; Hall, C.E.; Tyzack, G.E.; Ziff, O.J.; Greensmith, L.; Kalmar, B.; Ahmed, M.; Alam, A.; Thelin, E.P.; et al. Astrocytes display cell autonomous and diverse early reactive states in familial amyotrophic lateral sclerosis. Brain 2022, awab328. [CrossRef]

151. Bensimon, G.; Lacomblez, L.; Meininger, V.; The ALS/Riluzole Study Group. A Controlled Trial of Riluzole in Amyotrophic Lateral Sclerosis. N. Engl. J. Med. 1994, 330, 585-591. [CrossRef] [PubMed]

152. Petrov, D.; Mansfield, C.; Moussy, A.; Hermine, O. ALS Clinical Trials Review: 20 Years of Failure. Are We Any Closer to Registering a New Treatment? Front. Aging Neurosci. 2017, 9, 6. [CrossRef] [PubMed]

153. Dash, R.P.; Babu, R.J.; Srinivas, N.R. Two Decades-Long Journey from Riluzole to Edaravone: Revisiting the Clinical Pharmacokinetics of the Only Two Amyotrophic Lateral Sclerosis Therapeutics. Clin. Pharmacokinet. 2018, 57, 1385-1398. [CrossRef]

154. Jaiswal, M.K. Riluzole and edaravone: A tale of two amyotrophic lateral sclerosis drugs. Med. Res. Rev. 2018, 39, 733-748. [CrossRef] [PubMed]

155. Hogg, M.; Halang, L.; Woods, I.; Coughlan, K.S.; Prehn, J.H.M. Riluzole does not improve lifespan or motor function in three ALS mouse models. Amyotroph. Lateral Scler. Front. Degener. 2018, 19, 438-445. [CrossRef] 
156. Wright, A.L.; Della Gatta, P.A.; Le, S.; Berning, B.A.; Mehta, P.; Jacobs, K.R.; Gul, H.; Gil, R.S.; Hedl, T.J.; Riddell, W.R.; et al. Riluzole does not ameliorate disease caused by cytoplasmic TDP-43 in a mouse model of amyotrophic lateral sclerosis. Eur. J. Neurosci. 2021, 54, 6237-6255. [CrossRef]

157. Bellingham, M.C. A Review of the Neural Mechanisms of Action and Clinical Efficiency of Riluzole in Treating Amyotrophic Lateral Sclerosis: What have we Learned in the Last Decade? CNS Neurosci. Ther. 2011, 17, 4-31. [CrossRef]

158. Hoy, S.M. Onasemnogene Abeparvovec: First Global Approval. Drugs 2019, 79, 1255-1262. [CrossRef]

159. Spark Therapeutics, Inc. Luxturna. 2017. Available online: https://www.fda.gov/media/109487/download (accessed on 1 November 2021).

160. Amado, D.A.; Davidson, B.L. Gene therapy for ALS: A review. Mol. Ther. 2021, 29, 3345-3358. [CrossRef]

161. Dimidschstein, J.; Chen, Q.; Tremblay, R.; Rogers, S.; Saldi, G.-A.; Guo, L.; Xu, Q.; Liu, R.; Lu, C.; Chu, J.; et al. A viral strategy for targeting and manipulating interneurons across vertebrate species. Nat. Neurosci. 2016, 19, 1743-1749. [CrossRef]

162. Hoshino, C.; Konno, A.; Hosoi, N.; Kaneko, R.; Mukai, R.; Nakai, J.; Hirai, H. GABAergic neuron-specific whole-brain transduction by AAV-PHP.B incorporated with a new GAD65 promoter. Mol. Brain 2021, 14, 33. [CrossRef] [PubMed]

163. Goertsen, D.; Flytzanis, N.C.; Goeden, N.; Chuapoco, M.R.; Cummins, A.; Chen, Y.; Fan, Y.; Zhang, Q.; Sharma, J.; Duan, Y.; et al. AAV capsid variants with brain-wide transgene expression and decreased liver targeting after intravenous delivery in mouse and marmoset. Nat. Neurosci. 2021, 25, 106-115. [CrossRef] [PubMed]

164. Genç, B.; Jara, J.H.; Sanchez, S.S.; Lagrimas, A.K.B.; Gözütok, O.; Koçak, N.; Zhu, Y.; Özdinler, P.H. Upper motor neurons are a target for gene therapy and UCHL1 is necessary and sufficient to improve cellular integrity of diseased upper motor neurons. Gene Ther. 2021. [CrossRef] [PubMed]

165. Lim, C.K.; Gapinske, M.; Brooks, A.K.; Woods, W.S.; Powell, J.E.; Zeballos, M.A.C.; Winter, J.; Perez-Pinera, P.; Gaj, T. Treatment of a Mouse Model of ALS by In Vivo Base Editing. Mol. Ther. 2020, 28, 1177-1189. [CrossRef] [PubMed]

166. Klein, S.M.; Behrstock, S.; McHugh, J.; Hoffmann, K.; Wallace, K.; Suzuki, M.; Aebischer, P.; Svendsen, C.N. GDNF Delivery Using Human Neural Progenitor Cells in a Rat Model of ALS. Hum. Gene Ther. 2005, 16, 509-521. [CrossRef] [PubMed]

167. Kondo, T.; Funayama, M.; Tsukita, K.; Hotta, A.; Yasuda, A.; Nori, S.; Kaneko, S.; Nakamura, M.; Takahashi, R.; Okano, H.; et al Focal Transplantation of Human iPSC-Derived Glial-Rich Neural Progenitors Improves Lifespan of ALS Mice. Stem Cell Rep. 2014, 3, 242-249. [CrossRef]

168. Izrael, M.; Slutsky, S.G.; Admoni, T.; Cohen, L.; Granit, A.; Hasson, A.; Itskovitz-Eldor, J.; Paker, L.K.; Kuperstein, G.; Lavon, N.; et al. Safety and efficacy of human embryonic stem cell-derived astrocytes following intrathecal transplantation in SOD1G93A and NSG animal models. Stem Cell Res. Ther. 2018, 9, 152. [CrossRef]

169. Thomsen, G.M.; Avalos, P.; Ma, A.A.; Alkaslasi, M.; Cho, N.; Wyss, L.; Vit, J.-P.; Godoy, M.; Suezaki, P.; Shelest, O.; et al. Transplantation of Neural Progenitor Cells Expressing Glial Cell Line-Derived Neurotrophic Factor into the Motor Cortex as a Strategy to Treat Amyotrophic Lateral Sclerosis. Stem Cells 2018, 36, 1122-1131. [CrossRef]

170. Mishra, P.S.; Dhull, D.K.; Nalini, A.; Vijayalakshmi, K.; Sathyaprabha, T.N.; Alladi, P.A.; Raju, T.R. Astroglia acquires a toxic neuroinflammatory role in response to the cerebrospinal fluid from amyotrophic lateral sclerosis patients. J. Neuroinflamm. 2016, 13, 212. [CrossRef]

171. Liebscher, S.; Keller, G.B.; Goltstein, P.M.; Bonhoeffer, T.; Hübener, M. Selective Persistence of Sensorimotor Mismatch Signals in Visual Cortex of Behaving Alzheimer's Disease Mice. Curr. Biol. 2016, 26, 956-964. [CrossRef]

172. Busche, M.A.; Eichhoff, G.; Adelsberger, H.; Abramowski, D.; Wiederhold, K.-H.; Haass, C.; Staufenbiel, M.; Konnerth, A.; Garaschuk, O. Clusters of hyperactive neurons near amyloid plaques in a mouse model of Alzheimer's disease. Science 2008, 321, 1686-1689. [CrossRef] [PubMed]

173. Grienberger, C.; Rochefort, N.L.; Adelsberger, H.; Henning, H.A.; Hill, D.N.; Reichwald, J.; Staufenbiel, M.; Konnerth, A. Staged decline of neuronal function in vivo in an animal model of Alzheimer's disease. Nat. Commun. 2012, 3, 774. [CrossRef] [PubMed]

174. Korzhova, V.; Marinković, P.; Goltstein, P.M.; Herms, J.; Liebscher, S. Long-term dynamics of aberrant neuronal activity in Alzheimer's disease. bioRxiv 2019, 801902. [CrossRef]

175. Burgold, J.; Schulz-Trieglaff, E.K.; Voelkl, K.; Gutiérrez-Ángel, S.; Bader, J.M.; Hosp, F.; Mann, M.; Arzberger, T.; Klein, R.; Liebscher, S.; et al. Cortical circuit alterations precede motor impairments in Huntington's disease mice. Sci. Rep. 2019, 9, 6634. [CrossRef]

176. Ellwardt, E.; Pramanik, G.; Luchtman, D.; Novkovic, T.; Jubal, E.R.; Vogt, J.; Arnoux, I.; Vogelaar, C.F.; Mandal, S.; Schmalz, M.; et al. Maladaptive cortical hyperactivity upon recovery from experimental autoimmune encephalomyelitis. Nat. Neurosci. 2018, 21, 1392-1403. [CrossRef] [PubMed]

177. Taverna, S.; Ilijic, E.; Surmeier, D.J. Recurrent Collateral Connections of Striatal Medium Spiny Neurons Are Disrupted in Models of Parkinson's Disease. J. Neurosci. 2008, 28, 5504-5512. [CrossRef] [PubMed]

178. Blumenstock, S.; Schulz-Trieglaff, E.K.; Voelkl, K.; Bolender, A.; Lapios, P.; Lindner, J.; Hipp, M.S.; Hartl, F.U.; Klein, R.; Dudanova, I. Fluc-EGFP reporter mice reveal differential alterations of neuronal proteostasis in aging and disease. EMBO J. 2021, 40, e107260. [CrossRef]

179. Mentis, G.Z.; Blivis, D.; Liu, W.; Drobac, E.; Crowder, M.E.; Kong, L.; Alvarez, F.J.; Sumner, C.J.; O’Donovan, M.J. Early Functional Impairment of Sensory-Motor Connectivity in a Mouse Model of Spinal Muscular Atrophy. Neuron 2011, 69, 453-467. [CrossRef] [PubMed] 
180. Mukherjee, A.; Carvalho, F.; Eliez, S.; Caroni, P. Long-Lasting Rescue of Network and Cognitive Dysfunction in a Genetic Schizophrenia Model. Cell 2019, 178, 1387-1402.e14. [CrossRef] [PubMed]

181. Venkatesh, H.S.; Morishita, W.; Geraghty, A.C.; Silverbush, D.; Gillespie, S.M.; Arzt, M.; Tam, L.T.; Espenel, C.; Ponnuswami, A.; $\mathrm{Ni}$, L.; et al. Electrical and synaptic integration of glioma into neural circuits. Nature 2019, 573, 539-545. [CrossRef] 